\title{
ENTERPRISE LIABILITY AND THE EMERGING MANAGED HEALTH CARE SY STEM
}

\author{
WILLIAM M. SAGE
}

\begin{abstract}
।
INTRODUCTION

"E nterprise medical liability" is a term used to describe a system in which health care organizations bear responsibility for medical malpractice in addition to or instead of individual health professionals. ${ }^{1}$ Enterprise liability is in many senses a natural outgrowth of the increasing dependence of medical practice on institutional resources and expertise. ${ }^{2}$ Proposals for enterprise liability surfaced briefly from the academic literature into the political spotlight during the 1993-94 health care reform debate. A t that time, objections to the concept as a basis for medical malpractice liability, even in a restructured health care system, were nearly universal.

J ust five years later, many of the groups vehemently opposing the Clinton malpractice reform have become vigorous supporters of managed care liability. $^{3} \quad$ Moreover, courts and legislatures are holding managed care

Copyright (C 1997 by Law and Contemporary Problems

* A ssociate Professor of Law, Columbia U niversity.

The author thanks the conference participants for helpful comments and discussion, and David A nderson and J effrey Parnass for research assistance. The author extends special thanks to Bob Berenson for work on an earlier manuscript that provided background material for this article.

1. Several articles have been written about enterprise liability since the demise of the Clinton health plan. See Kenneth S. A braham \& Paul C. Weiler, Enterprise Medical Liability and the Evolution of the A merican Health Care System, 108 HARV. L. REV. 381 (1994); Barry R. Furrow, E nterprise $L$ iability and $\mathrm{H}$ ealth Care R eform: M anaging Care and M anaging Risk, 39 ST. L OUIS U. L.J . 77 (1994); Clark C. Havighurst, M aking Health Plans A ccountable for the Quality of Care, 31 G A . L. REV. 587 (1997); W illiam M. Sage et al., E nterprise L iability for M edical M al practice and Health Care Q uality Improvement, 20 A M. J.L. \& MED. 1 (1994).

2. Other professions are also having to deal with the complexity of modern practice and the potential for institutional responsibility. In law, for example, N ew $\mathrm{Y}$ ork recently became the first state to impose professional disciplinary rules on law firms in addition to individual lawyers. See N.Y. DISCIPLINARY RULES 1-102, 1-103, 1-105 (amended May 22, 1996). The New Y ork rules codify a judicial decision in favor of an attorney who had been discharged by his law firm for insisting that the firm divulge the misconduct of an associate. The Court of A ppeals held that there exists an unstated but essential compact intrinsic to the relationship between an attorney and a law firm that both will conduct legal practice in compliance with rules of conduct and professional ethical standards. See Weider v. Skala, 80 N.Y. 2d 628, 637 (N.Y. 1992).

3. These interest groups, including the A merican Medical A ssociation ("AMA"), do not generally acknowledge that their current lobbying efforts bear any resemblance to the much-deplored Clinton version of enterprise liability. On occasion, contemporary concepts are qualified in some respect to differentiate them from the Clinton proposal. M ore frequently, the connection is simply ignored (and perhaps unnoticed), obvious as it may seem.
\end{abstract}


organizations accountable for malpractice in ways superficially compatible with the Clinton proposal. In the process, however, enterprise liability has been transformed from a theory without a movement to a movement without a theory. This article explores why this happened, whether it is likely to be a transitory phase or a sustained trend, and what it portends for the public policy objectives of medical tort law.

Part II of this article describes the theoretical justifications for imposing liability for medical malpractice on managed care organizations, emphasizing proposals that were made in connection with the national health care reform debate. Part III explains why enterprise liability failed to attract support in 1993-94. Part IV discusses the very different attitudes that prevail in 1998, and details the legal manifestations of the current movement to expand malpractice liability in managed care. Parts V and VI of the article analyze the relationship among theoretical constructs of enterprise liability, the reality of today's managed care marketplace, and the legal response managed care has provoked. Specifically, Part V outlines several respects in which the market and the legal system have moved away from characteristics that previously made enterprise liability desirable, and Part VI identifies potentially significant trends that could lead to a rapprochement between our health care system and the public policy justifications for extending malpractice liability to managed care organizations. Finally, Part V II suggests that federal legislation is necessary for malpractice liability to serve socially constructive purposes in managed care, and identifies a set of principles that should guide future legislative action.

\section{ENTERPRISE LIABILITY IN THEORY}

Improving the A merican medical malpractice system will require a number of significant changes. The current structure provides poorly for the needs of negligently injured patients, encourages costly, contentious, and wasteful litigation, and is predisposed to both groundless lawsuits and excessive awards. Enterprise liability is not a panacea for all these ailments; rather it is one of several new approaches intended to promote fair compensation, clinical quality improvement, and administrative efficiency in a future health care system based primarily on managed care. ${ }^{4}$

A cademic views of the effectiveness of medical malpractice law as a compensatory mechanism and as a deterrent to carelessness have been shaped primarily by the $\mathrm{H}$ arvard M edical Practice Study, which attempted to measure the incidence of malpractice in N ew Y ork State hospitals in 1984. The Harvard Study concluded that, although approximately one percent of hospital admissions included a negligent event resulting in injury, there was a gross mismatch between negligently injured patients and patients receiving

4. See Eleanor D. Kinney, Malpractice Reforms in the 1990s: Past Disappointments, Future Success?, 20 J. HEALTH POL., POL'Y \& L. 99 (1995). 
compensation through malpractice litigation. ${ }^{5}$ A subsequent study drawn from the same data concluded that the severity of the patient's ultimate disability, not the existence of negligence or even the occurrence of an adverse event during medical treatment, predicted payments made in settlement or at trial. ${ }^{6}$ This evidence suggests that medical malpractice law provides compensation unevenly, directing windfall awards at some seriously injured patients, but leaving the majority of deserving claimants unsatisfied. ${ }^{7}$

The deterrent impact of malpractice litigation is also debatable. The malpractice system may contribute to policing flagrant recidivism among careless or incompetent physicians by rendering them uninsurable. However, its effectiveness at promoting quality at the margin is doubtful, especially given the discrepancy between deserving plaintiffs and judicial outcomes. ${ }^{8}$ Certainly, potential malpractice exposure increases clinical intrusiveness, but whether this "defensive medicine" represents appropriate care or wasteful overtesting and overtreatment remains unsettled. ${ }^{9}$ N either has definitive work established the extent of risk avoidance by physicians confronted with potentially litigious patients or extremely hazardous health conditions. ${ }^{10}$

Compounding its questionable effect on compensation and deterrence, the malpractice system is extremely time-consuming and expensive. ${ }^{11} \mathrm{M}$ alpractice

5. See harvard Medical Practice Study, Patients, Doctors and LaWyers: Studies OF MEDICAL INJURY, MALPRACTICE LITIGATION AND PATIENT COMPENSATION IN NEW YORK (1990); Troyen A . B rennan et al., Incidence of A dverse E vents and $N$ egligence in H ospitalized Patients: Results of the Harvard M edical Practice Study I, 324 NEW E NG. J. MED. 370 (1991); H oward H. H iatt et al., A Study of Medical Injury and M edical Malpractice: An O verview, 321 NEW E NG. J. M ED. 480 (1989); L ucian L. Leape et al., The Nature of A dverse Events in H ospitalized Patients: Results of the Harvard Medical Practice Study II, 324 NEW ENG. J. MED. 377 (1991); A. Russell Localio et al., Relation Between Malpractice Claims and Adverse Events Due to Negligence: Results of the $H$ arvard M edical Practice Study III, 325 N EW E NG. J. MED. 245 (1991). O nly one-eighth of the events judged to be negligent in the study led to malpractice litigation, and only half of those were eventually compensated. However, five claims were filed with respect to care not considered negligent for every valid one.

6. See Troyen A . B rennan et al., Relation B etween N egligent A dverse $E$ vents and the $O$ utcomes of M edical M alpractice L itigation, 335 NEW E NG. J. MED. 1963 (1996). In a general sense, then, medical mal practice law serves a compensatory function, but in a manner unrelated to causation or fault.

7. Cases with considerable legal merit but modest financial impact are of particular concern because most plaintiffs' attorneys will not pursue medical malpractice cases with potential recoveries under $\$ 50,000$. SeeU.S. General A cCOUnTING OfFICE, Medical MALPRACTICE: A FrameWork FOR A CTION (1987).

8. Coupled with a "small numbers" problem of individual physicians infrequently encountering claims, this mismatch also makes insurers unable to experience rate liability policies, tempering still further any deterrent effect.

9. See D aniel Kessler \& M ark M cClellan, D o D octors Practice D efensive M edicine?, Q.J . E coN., $M$ ay 1996, at 355, 388 (finding that states with tort reform laws have lower rates of increase in Medicare Part A costs).

10. See R andall R. B ovbjerg et al., D efensive M edicine and Tort R eform: $N$ ew E vidence in an Old Bottle, 21 J. HEA LTH POL., POL'Y \& L. 267 (Spring 1996). Physicians also may avoid high-risk patients for other reasons, such as the potential adverse effect on publicly released "report cards" listing surgeon mortality. See Eric C. Schneider \& A rnold M. Epstein, Influence of Cardiac-Surgery Performance Reports on R eferral Practices and A ccess to Care: A Survey of Cardiovascular Specialists, 335 NEW ENG. J. MED. 251 (1996).

11. If the malpractice system is so bad, one might ask why it even exists. Perhaps the answer is that, like democracy, it is the worst possible system except for all the others. 
claims take on average sixteen months to file and twenty-five months to resolve. ${ }^{12}$ Moreover, transaction costs consume well over half of premium dollars or jury awards, with attorneys' fees comprising much of this category. ${ }^{13}$

\section{A. E nterprise L iability and M anaged Care}

Legislatively imposed enterprise liability was conceived as a specific response to the anticipated growth of managed care and its potential effect on quality and safety. A s is now well known, managed care dramatically alters traditional relationships among payers, physicians, and patients. In many cases, patients look to managed care organizations to coordinate the delivery of medically appropriate services by qualified providers as well as to pay the bills. A nd, instead of merely seeking reimbursement, many physicians negotiate with health plans to establish contractual relationships that ensure a steady source of patients, and to develop policies for cost-effective treatment and referral that comport with professional standards.

Of course, the purpose of managing care is to control cost. Patients and physicians are concerned-quite justifiably-about the effect that a system driven by economics will have on quality of care and professional independence. Patients fear that care managers will pay insufficient attention to the clinical consequences of their actions and will engage in de facto rationing of expensive services. Physicians fear they will be caught between a rock and a hard place, beset on one side by arbitrary contracting policies and administrative requirements, and on the other by legal responsibility for suboptimal clinical outcomes. Enterprise liability for medical malpractice is a possible way to reduce conflict, curb abuses, and protect patients in a managed health care system.

\section{B. Proposals for Systematic E nterprise Liability}

In the early 1990s, two proposals were made to establish a model for enterprise liability that would replace suits against individual physicians: (1) a system of hospital-based liability proposed in 1992 by law professors Paul W eiler and K enneth A braham, ${ }^{14}$ and (2) a system of health plan-based liability considered in 1993 by President Clinton's Task Force on National Health Care

12. See medical malpractice SOlutions: Systems and Proposals for injury COMPENSATION 41 (M. Martin Halley et al. eds., 1989).

13. See, e.g., The URban Institute, Medical Malpractice: Problems \& Reforms: A POLICY-MAKER'S GUIDE TO ISSUESAND INFORMATION 14 (Intergovernmental Health Policy Project ed., 1995) (discussing 1985 R A N D study finding that plaintiffs received only $43 \%$ of their tort awards).

14. See KenNeth S. A BRAham \& PAUL C. WeILER, ROBERT WOOD JOHNSON FOUNDATION, ORGANIZATIONAL LIABILITY FOR MEDICAL MALPRACTICE: AN ALTERNATIVE TO INDIVIDUAL Health Care Provider Liability for Hospital Related MalpraCtice (1992); A braham \& W eiler, supra note 1; K enneth $S$. A braham et al., E nterprise R esponsibility for Personal Injury: Further Reflections, 30 SAN DIEGO L. REV. 333 (1993); Paul C. Weiler et al., Proposal for Medical Liability Reform, 267 JAMA 2355 (1992); see also II AMERICAN LAW INSTITUTE, REPORTERS' STUDY: ENTERPRISE RESPONSIBILITY FOR PERSONA L INJURY: A PPROACHESTO LEGA L AND INSTITUTIONAL CHA NGE (1991); Stephen D. Sugarman, A Restatement of Torts, 44 STA N. L. RE V. 1163 (1992). 
R eform. ${ }^{15}$ While each proposal had original elements, neither was cut from whole cloth. ${ }^{16}$

1. Hospital Liability. Weiler and A braham's proposal for enterprise medical liability assigned responsibility for physicians' negligence not to managed care organizations but to hospitals. The genesis of the proposal was primarily the savings that could be achieved by consolidating the defense of malpractice claims. ${ }^{17}$ B ecause the majority of medical malpractice cases arise from hospital care, and the most severe injuries occur in hospitals, it seemed natural that hospitals should assume the lead in defending lawsuits. It also occurred to Weiler and A braham that hospitals and other traditional health care facilities have established peer review procedures that would allow them to monitor the competence of physicians practicing within their walls, and to create environments that improve the quality of care.

Some recent trends cut against their approach, however. The current broad shift toward ambulatory and home-based care is resulting in a greater percentage of malpractice cases with no hospital involvement. In addition, hospitals are seldom contractually affiliated with physicians, except with respect to staff privileges. A s a result, physicians would receive a financial windfall from any transfer of liability, and hospitals would suffer a corresponding loss, unless totally unrelated third-party payers adjusted their reimbursement rates accordingly.

Despite these limitations, the Weiler and A braham proposal emphasized placing liability on the institution with the clearest involvement in health care delivery, rather than on individual physicians or purely financing entities such as insurers. ${ }^{18}$ The proposal thus anticipated to some degree the difficulties of institutional liability in the current managed care marketplace, where provider networks restructure frequently, and the name given to an organization, or even an organizational category, often indicates little about its actual function..$^{19}$ In addition, many hospitals are forming integrated delivery systems or acquiring physician practices in order to contract jointly with managed care organizations. H ospital-based liability could be efficient in these situations.

15. See Robert Pear, Clinton Advisors O utline Big Shift for Malpractice, N.Y. TIMES, May 21, 1993, at A 1; Sage et al., supra note 1; Elaine Zablocki, Tort R eform, H M O M A G., M ay/] une 1994, at 74.

16. See Barry R. Furrow, M edical Malpractice and Cost Containment: Tightening the Screws, 36 CA SE W. L. REV. 985, 1030-32 (1986) (discussing the possible effects of institutional liability); E. H aavi M orreim, Cost Containment and the Standard of M edical Care, 75 CA L. L. REV. 1719, 1746-50 (1987) (analyzing hospital and/or health plan liability); M yron F. Steves, J r., A Proposal to Improve the Cost to Benefit Relationships in the M edical Professional L iability Insurance System, 1975 D UKE L.J . 1305 (proposing transfer of medical malpractice liability to hospitals).

17. Several hospitals already had done so successfully through "channeling" programs. See infra text accompanying notes 73-74.

18. See K enneth S. A braham \& Paul C. Weiler, E nterprise M edical L iability and the Choice of the Responsible E nterprise, 20 A M. J .L. \& MED. 29 (1994).

19. Managed care consultants frequently observe that "if you've seen one managed care organization, you've seen one managed care organization." See infra text accompanying notes 162-78. 
2. Health Plan L iability. A s both a logical and a practical matter, adoption of enterprise liability during the 1993-94 health care reform debate relied on the concurrent passage of universal health coverage based on managed competition. ${ }^{20}$ This legislatively created managed health care system would have been composed of "health plans," that is integrated organizations that combined health care financing with the provision of services. Health plans might have been unitary corporations or contractual networks, and could have been owned or controlled by any combination of physicians, hospitals, insurers, and other health care entities. R egardless of their structure, however, health plans would have received a fixed annual payment, and would have been responsible for organizing and delivering necessary care to enrollees.

In an environment where health care is planned, managed, and provided by a "system" instead of being rendered by unaffiliated, individual practitioners, holding health plans primarily accountable for instances of medical malpractice is appealing for three reasons. First, health plans already would be primarily responsible for cost containment. L egal liability for negligent health outcomes therefore should make health plans reluctant to cut costs by reducing quality, especially when weighing aggregate budgetary concerns against the health needs of individual patients. Second, unlike torts that involve strangers (such as automobile accidents or toxic spills), medical malpractice arises between parties who have a pre-existing relationship, which health plans could formalize and extend. Health plans enroll beneficiaries using detailed insurance agreements, and rely on contractual relationships with providers to allocate financial risk, determine the price of services, and assure cost-consciousness. A s a whole, these agreements could form the basis for quality improvement activities, communication of grievances, and efficient dispute resolution. ${ }^{21}$ Third, health could be subjected to significant direct regulation and oversight. ${ }^{22}$ In the Clinton bill, for example, health plans were required to comply with national standards on the accessibility and impartiality of grievance procedures; to collect, process, and publish comprehensive information on clinical performance; and to work closely with purchasing alliances as well as with state and federal authorities to ensure access to and quality of care.

In theory, a well-managed health plan subject to enterprise liability would affiliate with high-quality providers, work to improve practice patterns through better information, seek out evidence of enrollee dissatisfaction, and move quickly to investigate and redress injuries. To accomplish this in the context of

20. See Health Equity and A ccess Reform Today Act, H.R. 3704, 103d Cong. (1993); Health Security A ct, H .R . 3600, 103d Cong. (1993); M anaged Competition A ct, H .R . 3222, 103d Cong. (1993).

21. For example, holding health plans primarily accountable would still permit hospital-based liability in cases where hospitals are best suited to manage cost and quality. A cademic health centers or other hospitals that serve patients covered by many health plans simply could assume liability from those health plans by contract.

22. See H.R. 3600, S. 1757, 103d Cong. (1993). R eflecting this high degree of regulatory scrutiny, the term "accountable health plan" was used in theoretical treatments of managed competition and in early drafts of the Clinton proposal. See Paul Starr \& Walter A. Zelman, A B ridge to Compromise: Competition Under a B udget, HEA LTH A FF., Supp. 1993, at 7, 13. 
comprehensive national health care reform, enterprise liability might have been designed according to the following principles:

(1) Each health plan that selectively contracts with or employs physicians, performs utilization review, and administers a quality improvement program would be liable for negligent injury to its enrollees caused by the health plan's affiliated practitioners and providers.

(2) Physicians and other health professionals practicing as employees of or under contract to such health plans would be granted legal immunity from suit. ${ }^{23}$

(3) Institutional providers, such as hospitals, that are well positioned to monitor and improve the quality of care within their organizations would be encouraged to assume liability for themselves and their affiliated physicians through indemnification or risk-sharing contracts with health plans.

(4) Less adversarial methods of dispute resolution such as arbitration, early offers of settlement, 24 "no-fault" compensation including "accelerated compensation events" ("ACEs"), 25 or other contractual alternatives to litigation would be permitted, so that health plans could compensate fairly and rapidly a greater percentage of injured patients.

(5) Legal limits on non-economic or punitive damages would be instituted to eliminate the threat of unreasonably large awards against corporate defendants, perhaps based on a sliding scale that accounts for severity and duration of injury. ${ }^{26}$

23. Health plans would be prohibited from requiring practitioners to indemnify them for malpractice losses or to purchase insurance, but would be allowed to adjust compensation or reimbursement by contract to reflect the shift in aggregate liability. In theory, there is no reason that individual physicians could not be liable as well, so long as plaintiffs generally elected to sue health plans. For example, this seems to be the pattern in litigation involving Kaiser Permanente. O $\mathrm{n}$ a widespread basis, however, allowing individual liability in a fully insured market would have risked perpetuating the current system. See infra text accompanying notes 181-82.

24. See Henson Moore \& J effrey $\mathrm{O}^{\prime}$ Connell, Foreclosing M edical Malpractice Claims by Prompt Tender of Economic Loss, 44 LA. L. REV. 1267, 1285 (1984); Jeffrey O'Connell, Neo-N o-Fault Remedies For Medical Injuries: Coordinated Statutory and Contractual Alternatives, 49 LAW \& CONTEM P. PROBS. 124 (Spring 1986).

25. See Laurence R. Tancredi \& R andall R . B ovbjerg, R ethinking R esponsibility for Patient Injury: A ccelerated-Compensation Events-A Malpractice and Quality Reform Ripe for a Test, 54 LAW \& CONTEMP. PROBS. 147 (Spring 1991).

26. See Randall R. Bovbjerg et al., Valuing Life and Limb in Tort: Scheduling "Pain and Suffering", 83 N W. U . L. REV. 908 (1989). 
(6) U naffiliated providers that elect to treat predominantly "out-ofnetwork" patients would be required to maintain individual malpractice insurance, and would be jointly liable with each injured patient's health plan. ${ }^{27}$

\section{Potential Benefits of E nterprise Liability}

In a reformed health care system based on managed care, enterprise liability offers several advantages over current malpractice law. These include higher quality care by virtue of a more focused deterrent effect, improved compensation for negligent injury, and reduced costs of administration.

1. Q uality I mprovement. The most important benefit of enterprise liability is that it could act as a potent counterweight to incentives to underserve captive populations of patients enrolled in managed care, while at the same time reducing physician-driven "defensive medicine." If health plans are held liable for patient injury, they might contract with providers and evaluate practice patterns based on quality instead of engaging in "economic credentialing." 28 At the same time, physicians-relieved of many concerns over individual liability-might participate more readily in cooperative decisionmaking and might be less resistant to clinical practice guidelines and other efforts by health plans to induce cost-effective practice on a system-wide basis.

Some commentators have argued that the management of cost and the delivery of clinical services should be kept separate by immunizing physicians from economic incentives and by preventing health plans from imposing utilization control procedures. ${ }^{29}$ In a cost-constrained environment, however, assigning malpractice liability only to individual physicians leads practitioners and managed care organizations to pull in opposite directions, discouraging coordination and teamwork in the provision of health care services. ${ }^{30}$ Given the need for efficiency in health care delivery, a system in which managers and physicians work at cross purposes is dysfunctional.

There is also reason to believe that health care enterprises would be effective at improving care. Experts on medical quality have long recognized the anomaly of focusing accountability on individual physicians. A S D onald Berwick observes, "[t]he doctor no longer really controls health care, as in the days of solo practice.... Control is shifting, structure is shifting, the pattern of

27. The theory of shared liability was to encourage physicians to join networks and health plans to improve their provider panels and reduce out-of-network utilization.

28. Economic credentialing is the phrase used to describe the practice of evaluating affiliated physicians based primarily on the costs they generate rather than the quality of their care.

29. See A rnold S. R elman, M edical Practice Under The Clinton Reforms-A voiding Domination By Business, 329 NEW ENG. J. MED. 1574 (1993).

30. In J une 1993, for example, the author participated in a discussion of health care reform among key stakeholders in New M exico. Most of the physicians present agreed on the need to improve the cost-effectiveness of clinical practice, but questioned how physicians could be expected to follow the conservative recommendations of health plans when they, not the health plans, were responsible for medical malpractice. 
care is shifting; but accountability is not." 31 For example, one quality-related benefit of enterprise liability involves information. M ost malpractice experts agree that a large percentage of malpractice suits result from miscommunication among providers and between providers and patients. ${ }^{32}$ Under enterprise liability, health plans would be responsible for errors in communication and would therefore invest more readily in support systems to enhance the amount, quality, and flow of information. ${ }^{33}$ In addition, the potential for enterprise liability based on lack of informed consent would likely encourage health plans to work with practitioners to assure that accurate information is provided to patients. ${ }^{34}$

A $n$ important caveat is that managed care organizations operating under the threat of liability may not always take constructive approaches to risk management. ${ }^{35}$ For example, a physician's livelihood may depend on entering into contracts with health plans. A Ithough enterprise liability should lead plans to value clinical quality more highly, it might also cause them to avoid affiliating with physicians who are at greater risk for litigation, even when the physician's ability is unquestioned.

2. Improved Compensation. A particular appeal of enterprise liability as part of national health care reform was the potential to improve the compensation of tort victims without greatly increasing costs. B ecause health plans must provide necessary treatment, they are automatically responsible for continuing medical care arising from iatrogenic injuries, including professional negligence. Given that future medical expenses comprise about twenty-five percent of damage awards in malpractice cases, some degree of compensation

31. Donald M. Berwick et al., Curing Health Care: new Strategies for Quality IMPROVEMENT 12 (1990). Studies of surgical hospitalizations, for example, have suggested that institutional and group characteristics predict performance to a greater degree than "surgeon effect." See Ann B. Flood \& W. Richard SCOTt, Hospital Structure and Performance 227-59, 347 (1987).

32. A recent study of intensive care concluded that adverse events were common and that more than one-fourth of them were due to misunderstandings between hospital staff members or administrative errors. See Lori A ndrews et al., A n A Iternative Strategy for Studying A dverse E vents in M edical Care, 349 L A NCET 309 (1997).

33. A dverse drug reactions are a significant cause of medical morbidity and mortality that often would be preventable through institutional surveillance. See, e.g., David W. B ates et al., The Costs of A dverse D rug E vents in H ospitalized Patients, 277 J A M A 307 (1997) (stating that preventable adverse drug events add nearly $\$ 3$ million to the annual cost of operating a large hospital); $D$ avid $C$. Classen et al., A dverse D rug E vents in H ospitalized Patients, 277 J A M A 301, 305 (1997) (finding that almost half of adverse drug events were preventable).

34. Several studies have established that poor communication between doctors and patients correlates strongly with malpractice litigation. See Gerald B. Hickson et al., Factors That Prompted Families to File M edical Malpractice Claims Following Perinatal Injuries, 267 J A M A 1359, 1361-63 (1992); see also Communicating Seen as K ey to M alpractice-Free Radiology, A MER. M ED. N EWS, J une 23, 1997, at 10. Moreover, new research in this issue suggests that institutional processes can help address these problems. See, e.g., G erald B. H ickson et al., D evelopment of an E arly Identification and Response Model of M alpractice Prevention, 60 LA W \& CONTEMP. PROBS. 7 (Winter 1997) (describing peer review of physicians who generate large numbers of patient complaints).

35. This certainly has been true of physicians, who both overtreat ("positive defensive medicine") and underserve ("negative defensive medicine"). 
is therefore automatically built into enterprise liability. 36

In addition, health plans participating in managed competition would be subject to regulatory oversight. A rguably, health plans' more direct incentive under enterprise liability to suppress evidence of malpractice makes monitoring essential. A t the same time, however, organizations would be somewhat easier to supervise than is currently the case with individual physicians, who tend to be both strategically and cognitively averse to acknowledging error. A mong other things, regulations could require plans to have ombudsman programs and structured grievance and appeals mechanisms. This would amplify patient "voice," bringing a greater percentage of injured patients to the attention of the malpractice system than typically occurs today through the entrepreneurial efforts of plaintiffs' attorneys.

3. A dministrative Efficiency. Imposing enterprise liability on health plans might result in the establishment of explicit contractual arrangements between health plans and patients for addressing most disputes over possible negligence. In California, for example, K aiser-Permanente not only assumes liability for its affiliated physicians but resolves allegations of negligence using courtapproved, binding arbitration. ${ }^{37}$ A Ithough enterprise liability is not necessary for health plans to adopt structured alternatives to litigation, fewer health plans are likely to devise fair, enforceable dispute resolution systems in its absence. ${ }^{38}$

Even without contractual forms of dispute resolution, enterprise liability has the potential to improve efficiency in the prevailing court-based system if it consolidates the defense of malpractice actions. Given that approximately twenty-five percent of malpractice suits involve more than one defendant, 39 enterprise liability could substantially reduce the transaction costs created by multiple parties with conflicting interests in terms of court costs, attorneys' fees, and the potential for strategic behavior in settlement negotiations and litigation tactics.

Finally, enterprise liability might improve the market for malpractice

36. See Harvard Medical Practice Study, supra note 5, at 8 . This is not entirely a theoretical point, even though large components of future medical expenses, such as long-term and custodial care, seldom are covered by standard health insurance. M any quality-related practices in managed care, including disease prevention, detection, and early treatment, depend on managed care organizations having long-term commitments to their enrollees. Single-year insurance contracts and high market turnover dilute the incentives for these activities. On the other hand, ease of consumer exit also may be important to promoting quality-based competition, especially in cases where patients have received unsatisfactory care.

37. See M adden v. K aiser Found. H osps., 17 Cal. 3d 699 (1976) (upholding mandatory arbitration of medical malpractice claims). But see E ngalla v. Permanente M ed. G roup, 115 Cal. 4th 951, modified by 1997 W L 426233 (1997) (holding K aiser liable for fraudulent failure to fulfill its obligations under its arbitration program). See also infra text accompanying notes 157-161.

38. M any insurers (and contracting organizations such as PPOs) neither claim nor acknowledge a relationship between their role in health care financing and the incidence of medical malpractice. Consequently, few statements of coverage address dispute resolution in malpractice cases. See Elizabeth Rolph et al., Arbitration Agreements in Health Care: Myths and Reality, 60 LAW \& CONTEM P. PR OBS. 153 (Winter 1997); see also infra text accompanying notes 118-24.

39. See U.S. General A cCounting Office, Medical Malpractice: Characteristics of CLA IM S CLOSE D IN 1984 (1986). 
insurance. $\mathrm{H}$ ealth plans and other large institutions would be able to diversify their insurance premiums across a full range of practitioners and services, reduce administrative costs, and self-insure or drive a hard bargain with insurance carriers. B y spreading malpractice risk, enterprise liability might also help improve access to services, such as obstetrical care, for which high malpractice premiums and small risk pools have limited the availability of providers in some geographic areas. ${ }^{40}$

\section{THE LIMITED INITIA L A PPEA L OF ENTER PRISE LIA BILITY}

Despite its theoretical promise, the Clinton Administration's enterprise liability proposal fell flat. The concept came into public view as a "trial balloon" of the Administration's health care task force in A pril 1993, immediately floated into a storm of opposition, and quickly proved leaden. Intended both as a policy-based imposition of responsibility on managed care plans in recognition of their expanded role, and as a political benefit to doctors who would be liberated from the threat of individual lawsuits, enterprise liability provoked a reaction that took its proponents by surprise. ${ }^{41}$ In retrospect, the criticism related less to the proposal per se than to what its announcement indicated about the direction of change in the A merican health care system.

\section{A. Public Perceptions}

Enterprise liability went against the conventional wisdom of medical malpractice in several major respects. First, patients and the medical profession were uncomfortable with the notion of "corporate healing," while enterprise liability explicitly acknowledged that health care has become more an institutional process than a series of discrete interactions between patients and individual physicians. Second, most physicians and much of the public believed that medical litigation benefited lawyers more than patients, 42 while enterprise liability relied on existing tort law to create incentives for quality improvement and appropriate compensation.

A third reason that proposals for structured forms of enterprise liability did not strike a responsive chord with the general public was the paucity of litigation involving managed care. A cademics had predicted a torrent of malpractice suits against managed care organizations for nearly a decade, but

40. See Dana Hughes et al., O bstetrical Care for L ow-Income Women: The Effects of Medical Malpractice on Community Health Centers, in II MEDICAL PROFESSIONAL LIABILITY AND THE DELIVERY OF OBSTETRICA L CARE (V irginia P. R ostow \& Roger J. Bulger eds., 1989).

41. See The Sinking of Enterprise L iability, A M. MED. NEWS, July 5, 1993, at 17. On the other hand, enterprise liability received support from employer coalitions such as the Washington Business $G$ roup on Health and professional societies such as the A merican N urses A ssociation.

42. Medical malpractice was one of several important discontinuities between the policy community and public opinion in 1993-94. See R obert J. Blendon et al., Bridging the G ap Between Expert and Public Views on H ealth Care Reform, 269 J A M A 2573 (1993). 
only a trickle had materialized by the time of the 1993-94 health care reform debate. ${ }^{43}$ Simple ignorance may be the most likely explanation for this. A the time, few lawyers (or potential plaintiffs) understood what managed care was, much less the influence it was beginning to have on A merican health care.

\section{B. Interest G roup Politics}

Enterprise liability also offended important political constituencies. Organized medicine's reaction was particularly violent, though easily explainable with hindsight. For one, the fact that enterprise liability applied to health plans signaled the Clinton A dministration's commitment to managed care for its still undisclosed health care reform proposal.44 This alone confirmed the worst fears of the medical profession. ${ }^{45}$ Medicine viewed enterprise liability as an embodiment of the threat large corporate organizations posed to professional practice. For example, organized medicine feared that, if held liable, health plans would summarily terminate high-risk physicians and micromanage clinical practice. ${ }^{46}$

A nother reason physicians opposed enterprise liability was its lack of resemblance to more familiar legislative changes affecting medical malpractice. Physicians had spent the previous two decades lobbying for barriers to litigation and limitations on recovery as the sole components of malpractice reform, using California's MICRA statute as the prototype. ${ }^{47}$ For the Clinton A dministration to proffer a shift or even arguably an expansion of liability as "tort reform" seemed a cruel joke to veterans of medicine's long-standing campaign against the trial bar.

43. See Rand institute for Civil Justice, health Care Delivery and Tort: Systems ON A COLLISION COURSE? (Elizabeth Rolph ed., 1991); William A. Chittenden III, Malpractice L iability and M anaged $\mathrm{H}$ ealth Care: $\mathrm{H}$ istory and Prognosis, 26 TOR TS \& INS. L.J . 451 (1991).

44. A s with many rumors at the time, this turned out not to be entirely true. The final $\mathrm{H}$ ealth Security A ct saddled managed care with a variety of surcharges and restrictions in order to subsidize the continuation of fee-for-service practice in M edicare and elsewhere. A t the time the public became aware of enterprise liability, however, not even a preliminary draft of the overall legislation had been released (or composed, for that matter).

45. Fear of managed care also may explain the lack of enthusiasm for enterprise liability among organized consumer advocacy groups, which normally are staunch defenders of the tort system. See Vicki Kemper, L awyers on Trial: O $\mathrm{C}$ Capitol $\mathrm{H}$ ill, the Trial L awyers $\mathrm{N}$ ever L ose ... E ver. B ut That M ay Be A bout to Change, COMM ON CA U SE M A G., (Summer 1993) (quoting J oan Claybrook as saying that "[t]he tort system is the only part of our economic system geared to representing the individual citizen"). In addition, consumer groups may have recognized (as may have the trial bar) that any version of enterprise liability actually incorporated into a health care reform plan would have included "compromise elements" such as mandatory dispute resolution or caps on damages.

46. One rhetorical consequence was to introduce an Alice-in-Wonderland version of rights discourse to the medical malpractice debate, based on the old management axiom "no responsibility without control." The author recalls a personal conversation with Robert A. Berenson, wherein Berenson recounted that at a contentious 1993 meeting of the Physician Insurers A ssociation of A merica, one irate medical leader went so far as to condemn enterprise liability for violating his "constitutional right to be sued." A the same time, of course, the managed care industry protested against enterprise liability on the ground that it could not control the behavior of physicians.

47. See Medical Injury Compensation R eform A ct of 1975 (MICRA), codified at CAL. BUS. \& Prof. CODE $\S 6146$ (West 1994), CAL. CIV. COdE $\S 3333$ (West 1994), CaL. CIV. ProC. COdE $\S \S$ 340.5, 1295 (W est 1994). 
Enterprise liability also posed a danger to one of the least visible but most influential groups involved in the medical malpractice system: liability insurers. The proposal would have restructured the market for liability insurance in two ways. First, larger organizations bearing malpractice risk would be more likely to self-insure and less likely to require commercial coverage. Second, exclusive health plan liability would reduce the power of physician-owned insurance companies, leading to competition between those companies and the organizations that insure hospitals and other institutions. ${ }^{48}$ Because many physician-owned insurers maintain close financial and managerial ties to county and state medical societies, their business concerns were converted quickly to political action.

N either did enterprise liability enthrall plaintiffs' lawyers. A ttorney lobbies were more concerned with imminent and potentially adverse changes in securities and product liability law than with the more speculative realm of health care reform. ${ }^{49} \mathrm{M}$ anaged care had not yet acquired the dubious reputation among the general public that would make it an attractive defendant to put in front of a civil jury. In addition, the specialized medical malpractice bar was accustomed to bringing suits against doctors and hospitals, 50 but had little notion of insurance law or ERISA .51 Moreover, liability insurance was entrenched firmly in the physician model, so that a deep pocket was already available, and settlement negotiations could be conducted through established relationships between plaintiffs' lawyers and defense counsel.

\section{IV}

\section{The Movement to Managed CARe Liability}

Since 1993, however, expanding malpractice liability to include managed care organizations has become the rage. There is currently little trace of the opposition or even apathy toward enterprise liability that prevailed among key constituencies during the health care reform debate. In basic terms, three things happened: Physicians got squeezed, patients got scared, and lawyers got interested.

Physicians in much of the country were surprised to discover that the defeat

48. These so-called "bedpan mutuals" have been regarded as saviors by physicians ever since the "crisis of availability" of malpractice insurance during the 1970s when commercial companies were deserting them. See Paul C. W eiler, Fixing the Tail: The Place of M alpractice in $\mathrm{H}$ ealth Care R eform, 47 R UTGERSL. REV. 1157, 1191 (1995).

49. In any event, the Clinton Administration's 1,600-plus page Health Security A ct was a full employment act for attorneys with health care expertise.

50. In states with strict tort reforms like California, only a small number of legal practitioners worked in medical malpractice, and the area was not thought sufficiently lucrative to attract other lawyers.

51. See infra text accompanying notes 77-85. Because of this inexperience, ERISA 's preemptive scope may have been especially daunting to plaintiffs' attorneys when the occasional complaint filed against a managed care organization was answered with motions to remove to federal court and to dismiss. 
of the Clinton health plan could not keep managed care from coming. ${ }^{52}$ $M$ anaged care took control anyway, and was allowed much freer rein than if comprehensive health care reform legislation had accompanied it. A mong other things, health plans terminated high-cost physicians (whether because of sicker-than-average patient populations or expensive practice styles), and imposed strict utilization standards on clinical decisions. Regardless of the actual or potential consequences of their actions, health plans generally disclaimed moral responsibility for patient care, citing doctors' duty to ensure quality, and legal liability, citing ERISA preemption. ${ }^{53}$ I nitially, courts tended to agree in both respects, putting physicians in the difficult position of trying to protect themselves in a relationship where, because of market conditions, they had little leverage. ${ }^{54} \mathrm{H}$ aving learned these hard lessons, organized medicine now endorses proposals to make malpractice claims more accessible in managed care-reversing not only its opposition to the Clinton proposal but several decades of resistance to the use of tort litigation as a quality improvement tool. 55

$\mathrm{M}$ anaged care as a threat to quality also began to resonate with consumers, whose fears had been aroused during the bitter political rhetoric of the health care reform debate. The chronic unpopularity of the insurance industry in general, combined with specific journalistic exposés of managed care, frightened the public and sent it seeking legislative relief.56 Physicians' vocal antipathy to managed care reinforced consumers' concerns. Entrepreneurial lawyers quickly capitalized on these trends, often invoking the manifest unfairness of ERISA preemption to garner sympathy for their position. ${ }^{57}$ E ven the so-called Republican revolution of 1994, including a provision in the Contract With A merica promising broad tort reform, could not stem the growing tide of resistance to the perceived power of managed care organizations. $^{58}$

52. Cf. Theodore Geisel, How the Grinch Stole Christmas (1957) ("He hadn'T stopped Christmas from coming! IT CA ME !/Somehow or other, it came just the same!").

53. See infra text accompanying notes 99-142.

54. See, e.g., Corcoran v. U nited Healthcare, Inc., 965 F.2d 1321 (5th Cir. 1992) (holding that patient arguably injured by action of utilization review contractor had no meaningful remedy because of ERISA ); Wickline v. California, 192 Cal. A pp. 3d 1630 (1986) (noting the potential for managed care liability in dictum, but refusing to excuse physician from obligation to advocate for patient's interests).

55. The AMA also has muted its opposition to enterprise liability per se, acknowledging it as an alternative to traditional tort reform worth continued evaluation. The AMA's policy objective for managed care liability is now tactfully stated as "that ... all managed care organizations ("M CO s") are held responsible for assuring quality healthcare, and are held liable for any negligence on the part of the health plan resulting in patient injury." AMERICAN MED. ASS'N, REPORT OF THE BOARD OF TRUSTEES 18-I-96 (1996).

56. A t the same time, many legislators and their families also were apprehensive about managed care, or had suffered difficulties accessing care or resolving billing issues.

57. See R obert Pear, H.M.O.'s U sing Federal L aw to D eflect Malpractice Suits, N.Y. TIM ES, Nov. 17, 1996, at A 3.

58. Fee-for-service medicine's longstanding support of the Republican Party prompted several inconsistencies between Congress's positions on health care and on other industries. In addition to supporting tort liability for managed care organizations while opposing it more generally, the 
The adverse publicity surrounding health care cost-containment and the inevitable horror stories attributable to managed care also grabbed the attention of trial lawyers. ${ }^{59}$ Moreover, in cases not subject to ERISA, the prevalence of corporate rather than individual defendants in managed care litigation, and the potential inapplicability of traditional tort reform laws, dangled the carrot of large punitive damage awards before plaintiffs' lawyers. ${ }^{60}$ In 1995, three of the nation's ten largest jury verdicts involved health care institutions. 61

\section{A . E stablished Forms of Corporate L iability}

Much as the enterprise liability proposals made during the national health care reform debate were not written on a blank slate, the ongoing expansion of managed care liability reflects the fact that courts long have been cognizant of corporate trends in health care delivery. It would be surprising indeed if health care enterprises that have become more than passive facilitators of physiciandetermined care should escape legal accountability for their actions. ${ }^{62}$ A s the Physician Payment Review Commission observed in its 1994 Report to Congress, "[e]nterprise liability is probably an inevitable result of legal trends and the incentives sharpened by increased competition in the medical marketplace." 63

1. Vicarious L iability. O ver the last few decades, courts developed at least four rationales for imposing liability on health care entities whose relationships with patients and physicians potentially affect the quality of care. Two doctrinal approaches impute to organizations responsibility for the actions of individual physicians. ${ }^{64}$ First, under the long-standing principle of respondeat superior, employers are generally liable for the acts of their employees. A s a result, government health systems such as the Veterans Administration,

R epublican Congress proposed antitrust exemptions for doctors despite a general commitment to freemarket competition, and showed a willingness to regulate managed care at the risk of increasing health costs for employers.

59. See Roger Parloff, The HMO Foes, A M. LAW., July/A ug. 1996, at 80; B erkeley Rice, L ook Who's on the M al practice H ot Seat N ow, 73 M ED. E CON. 192 (1996).

60. See Fox v. Health Net, No. 219692 (Riverside Super. Ct., Mar. 26, 1994) (jury award of $\$ 12$ million in compensatory and $\$ 77$ million in punitive damages against $\mathrm{HMO}$ for bad faith denial of insurance coverage and intentional infliction of emotional distress in HD C-A B M T breast cancer case). In Fox, ERISA defenses were unavailable because the plaintiff was a public schoolteacher. See id.

61. The usual number in previous years was one or two. See Verdict Trends in $1995 \mathrm{D}$ isregard the Clamor: Congressional Tort Revision U proar Has Had Little E ffect, NA T'L. L.J., Feb. 5, 1996, at C2 ("M edical malpractice awards, which had been falling dramatically in recent years, are on the way up again."). 115.

62. The effect of ERISA, of course, is one such surprise. See infra text accompanying notes 99-

63. Physician Payment Rev. Comm'n, 1994 Annual Report to Congress 299 (1994) [hereinafter 1994 PPR C REPORT].

64. Unlike legislative proposals for enterprise liability, legal doctrines holding organizations vicariously liable for the actions of physicians depend on underlying individual liability rather than replacing it. 
academic and public hospitals with full-time medical staffs, and staff-model $\mathrm{H}$ ealth Maintenance Organizations ("HMOs") are wholly responsible for the negligence of their employed physicians. Second, state courts have used the doctrine of ostensible (or apparent) agency, sometimes called agency by estoppel when reliance is present, to hold hospitals and health maintenance organizations vicariously liable for the negligence of non-employee physicians if the health care enterprise has advertised or otherwise held itself out as assuring the quality of its affiliated staff or provider network. ${ }^{65}$ Even in the absence of marketing activities or other explicit conduct, some courts have imposed a non-delegable duty on hospitals to provide certain physician services, and have therefore held hospitals vicariously liable for physician malpractice. ${ }^{66}$ Iterated vicarious claims are also possible. In one case, an HMO was held liable for the acts of consulting specialists selected by the H M O's staff physicians. ${ }^{67}$

2. Direct Liability. Lawsuits have successfully held health care organizations liable for the direct consequences of their actions as well, with or without claims being made against individual physicians. First, direct malpractice liability has roots in hospital peer review procedures. Health care facilities have long been responsible for reviewing the credentials of staff physicians and for monitoring performance to ensure that minimum standards of patient care are maintained. 68

Second, state courts have begun to recognize the increasing oversight of medical practice by health insurers and have made likely the imposition of liability based on negligent utilization review or the use of substandard clinical practice guidelines. ${ }^{69}$ In the first case to be litigated on this theory, Wickline $v$. State of California, ${ }^{70}$ the court did not find liability, but observed that " $[\mathrm{t}] \mathrm{hird}$ party payors of health care services can be held legally accountable when medically inappropriate decisions result from defects in the design or implementation of cost containment mechanisms."

3. Private Contracting. Malpractice liability may be redistributed by contract as well as by judicial fiat. $^{72}$ Several health care organizations

65. See B oyd v. A lbert E instein M ed. Ctr., 547 A .2d 1229 (Pa. Super. 1988); Kashishian v. Port, 481 N.W.2d 277 (W is. 1992).

66. See J ackson v. Power, 743 P.2d 1376 (A laska 1987); see also M cClellan v. H ealth Maintenance O rg., 604 A.2d 103 (Pa. Super. 1992).

67. See Schleier v. K aiser Found. Health Plan, 876 F.2d 174 (D.C. A pp. 1989).

68. See Darling v. Charleston Community Mem'I Hosp., 211 N.E.2d 253 (III. 1965); David H. R utchik, The E merging Trend of Corporate L iability: Courts' Uneven Treatment of H ospital Standards L eaves H ospitals U ncertain and Exposed, 47 V A ND. L. REV. 535 (1994).

69. See W ilson v. B lue Cross, 271 Cal. R ptr. 876 (Ct. A pp. 1990).

70. 192 Cal. A pp. 3d 1630 (1986).

71. Id. at 1645.

72. See Richard A. Epstein, Contracting Out of the Medical Malpractice Crisis, 20 PERSP. BIOLOGY \& MED. 228 (1977); M ax W. Fine \& J onathan H. Sunshine, M alpractice Reform Through Consumer Choice and Consumer Education: A re New Concepts Marketable?, 49 LA W \& CONTEMP. PROBS. 213 (Spring 1986); William M. Sage \& James M. Jorling, A World That Won't Stand Still: 
voluntarily involve themselves in medical malpractice issues that affect their affiliated physicians. For example, the Jewish Philanthropic Hospital A ssociation in N ew $\mathrm{Y}$ ork City and the $\mathrm{H}$ arvard M edical Institutions in B oston have for many years sponsored "channeling" programs through which they purchase malpractice coverage for their non-employed medical staffs. $^{73}$ However, these institutions do not formally accept liability for the acts of the insured physicians. Channeling is designed primarily to provide less expensive insurance coverage for physicians and to reduce administrative costs by allowing a single insurer and its attorney to represent both the institution and the physician in the event of a suit. ${ }^{74}$

Finally, some integrated health care organizations have expressly assumed liability for their affiliated physicians. For example, Kaiser Foundation $\mathrm{H}$ ealth Plan, a group-model H M O that contracts with but does not employ physicians, has in place a long-term agreement to indemnify and defend the Permanente Medical Group, a physician partnership, against judgments arising from malpractice affecting Kaiser patients. ${ }^{75}$ Recently, more loosely organized health care networks and health systems have offered to bear responsibility for malpractice as a way to attract and retain physicians. ${ }^{76}$

\section{B. R ecent L egal Trends}

A s described above, corporate responsibility for medical malpractice had acquired a secure foothold in tort law long before systematic forms of enterprise liability were proposed. Courts and legislatures are now building on these foundations in response to the rapid growth of managed care.

1. Litigation. A lthough up-to-the-minute data on health care litigation are scarce, anecdotal evidence suggests a heavy downpour of suits against managed care organizations. In part, this reflects the delay inherent in litigation, so that injuries suffered five years ago are only now reaching final determination. B ut there are also other forces at work, some related to managed care itself and others to the legal system's response to managed care.

In addition to implicating previously sheltered parties such as insurers,

Enterprise L iability by Private Contract, 43 D E PA U L L. R E V. 1007 (1994).

73. See James F. Holzer, Channeling Programs Aid MD-Hospital Cooperation, HosP., A pr. 5, 1987, at 92; A nn P. W ood, Channeling: M edical L iability I nsurance Concept B eing Widely D iscussed by Hospitals, PEDIA TRIC NEWS, Jan. 1987, at 10.

74. See M edical Malpractice Recommendations for the State of $N$ ew $Y$ ork: Executive Summary, in 45 RE CORD OF THE A SSOCIATION OF THE BAR OF THE CITY OF NEW Y ORK 573 (1990).

75. It is worth noting that $\mathrm{K}$ aiser has elected to assume malpractice liability only in jurisdictions such as California that allow mandatory arbitration of claims and place caps on non-economic damages. See supra notes 37, 47.

76. See P. Crabtree, H M O s H eld M ore A ccountable for Care, SAN DIEGO BU S. J., N ov. 8, 1993, at 1; E dward Felsenthal, M edical Plans A re Shouldering M ore L iability for D octor's E rrors, W A LL ST. J., Oct. 18, 1993, at B 8. Because assumption of liability may be construed as a benefit paid in exchange for referrals, federal fraud and abuse laws present an obstacle to these transactions, at least when hospitals are involved. See discussion infra note 196. 
managed care presents opportunities for new causes of action, and reshuffles liability exposure among traditional physician and hospital defendants. ${ }^{77}$ To date, managed care has saved money primarily by reducing inpatient hospitalization and surgery-directly through preauthorization requirements and indirectly by using primary care gatekeepers to limit access to specialist physicians. Managed care also has used a combination of rules and financial incentives to decrease utilization at the margin, particularly for ancillary services such as laboratory testing and radiological studies. ${ }^{78}$

$E$ ach of these raises malpractice concerns. A Ithough the majority of serious claims still arise in hospitals, a shift to outpatient care means less malpractice exposure for facilities and more for physicians and utilization review entities, especially if failure to hospitalize or operate is associated with injury. R eliance on primary care physicians for screening and coordination means more claims for failure to diagnose and failure to refer. ${ }^{79} \mathrm{U}$ sing the theories of tort law discussed above, managed care organizations can be held directly or vicariously liable for all of these claims. In one recent case, a M edicare H M O member was awarded $\$ 1.1$ million by an arbitrator, including $\$ 100,000$ in punitive damages, for injuries resulting from delays in diagnosing renal failure. ${ }^{80}$ In another case, a jury awarded $\$ 3$ million (reduced under MICRA to $\$ 700,000$ ) for failure to refer for diagnosis of colon cancer, based in part on evidence of financial incentives to deny care. ${ }^{81}$

In a situation that exemplifies the emotionally charged environment surrounding managed care and malpractice, Kaiser recently settled for $\$ 5.35$ million a Texas wrongful death suit involving failure to diagnose coronary

77. For a detailed discussion of many of these issues, see MANAGED CARE LIABILITY (D avid L. Leitner ed., 1996); Barry R. Furrow, Managed Care Organizations and Patient Injury: Rethinking L iability, 31 G A. L. REV. 419 (1997).

78. Rules include utilization review standards and clinical protocols. Incentives include bonuses and capitation. See A lan L. Hillman, Managing the Physician: Rules Versus Incentives, 10 HEA LTH A FF. 138 (Winter 1991).

79. See Linda O. Prager, G atekeepers on Trial: Primary Care Liability Risks A re Rising with Growth of M anaged Care, A M. MED. NEWS, Feb. 12, 1996, at 1. M oreover, because invasive medical procedures have become the mainstay of modern, fee-for-service practice, primary care physicians (at least those who do not perform deliveries) traditionally had both lower income and lower malpractice insurance expenses than specialists. $M$ anaged care gatekeeping not only increases liability exposure based on omissions, but induces primary care physicians to perform more procedures themselves. W hether primary care earnings have matched increased liability insurance premiums is an interesting empirical question.

80. The case, Ramey v. Inter Valley Health Plan, is described in David R. O Imos, Pomona H M O Found L iable in M alpractice Case, L.A. TIMES, J uly 10, 1997, at D 1, D 10. A s a M edicare case, it was not subject to ERISA, and it was brought as a suit for breach of faith and negligence, which arguably exempted it from MICRA as well. U nlike ERISA, M edicare's provisions for administrative resolution of benefit denials have been held not to preempt state law tort claims. See A rdary v. A etna Health Plans, Inc., 98 F.3d 496 (9th Cir. 1996). However, it is unclear when Medicare managed care beneficiaries may bring state court actions without first exhausting federal administrative remedies. See, e.g., R edmond v. Secure H orizons, Pacificare, Inc., 60 Cal. A pp. 4th 96 (1997) (holding that claims for reimbursement for wrongfully denied coverage, unlike wrongful death claims, require prior exhaustion of M edicare's administrative review process). This is yet another example of how the law ascribes continuing importance to a distinction-between benefits and treatment decisions-that is increasingly hard to make in practice. See infra text accompanying notes 118-24.

81. See Ching v. G aines, N o. 137656 (V entura C ty. Super. Ct., N ov. 30, 1995). 
artery disease. $^{82}$ The settlement was reached after a non-binding "summary jury" recommended a $\$ 62$ million award because an associate medical director had remarked at an industry conference that Kaiser's utilization decisions were financially motivated. A BC News devoted an entire episode of "Nightline" to the case, introducing it with the line: "Tonight, the nation's wealthiest H MO and why a jury was left outraged." ${ }^{83}$

Because they explicitly serve populations of beneficiaries, not just individual patients, managed care organizations also can be subjected to class action litigation over some of these practices. A lthough class certification and problems of proof may represent significant hurdles for plaintiffs' lawyers, 84 flawed clinical practice guidelines, systematically biased utilization review, or heavy-handed physician financial incentives could conceivably form the basis of liability, with the potential for substantial damages. These rewards seem to be attracting class action specialists whose securities fraud or product liability practices have declined. .5

2. L egislation. As managed care becomes a political target, legislative measures to hold managed care organizations liable for malpractice are being widely debated and enacted. Some of this activity has been necessary because of an unexpected barrier to the judicial imposition of liability: state statutory prohibitions on the corporate practice of medicine. These laws often date from the early years of the century, but have seldom been enforced in most states. ${ }^{86}$ Nonetheless, case law in a few states-notably Texas and New Y ork- has established that if health care organizations cannot practice medicine, neither can they commit malpractice. ${ }^{87}$

82. See Karen B rooks, Accord Reached in Irving Health Suit, FT. W ORTH STAR-TELEGRA M, Dec. 17,1997 , at 1.

83. Nightline (A BC television broadcast, Feb. 13, 1998).

84. Differences in injuries suffered, factual bases for defenses, and, in federal diversity actions, legal rights and remedies under diverse state laws may hinder class certification, even for purposes of settlement rather than prosecution. See A mchem Prods., Inc. v. Windsor, 117 S. Ct. 2231 (1997); Castano v. A merican Tobacco, 84 F.3d 734 (5th Cir. 1996).

85. M ost class actions against managed care organizations have been brought on fraud theories in situations involving economic rather than physical injury. See, e.g., M cConocha v. Blue Cross and Blue Shield, 898 F. Supp. 545 (N.D. O hio 1995) (involving suit to recover overstated co-payments caused by defendant's failure to acknowledge discounts received from providers). Malpractice cases will often, but not always, derive from unique circumstances that argue against class treatment. See Kathy $L$. Cerminara, The Class A ction as a M ethod of Patient E mpowerment in the M anaged Care Setting, 24 A M.J.L.\& MED. (forthcoming 1998).

86. See Patricia F. Jacobson, Prohibition A gainst Corporate Practice of Medicine: Dinosaur or Dynamic Doctrine?, in 1993 HEALTH LAW HANDBOOK 67 (A lice G. Gosfield ed., 1993). Recently, corporate practice laws have enjoyed a resurgence as a strategic counterweight to the employment of physicians by hospitals and managed care organizations. See Berlin v. Sarah B ush Lincoln H ealth Ctr., 664 N.E.2d 337 (III. A pp. Ct. 1996), rev'd, 688 N.E.2d 106 (III. 1997) (intermediate court ruling voiding physician's employment contract with hospital as contrary to Illinois prohibition on corporate practice). The Illinois Supreme Court's decision in Berlin retains the prohibition on physician employment by general corporations, but allows hospitals to employ physicians because hospitals are already licensed by the state to provide health care services.

87. See Williams v. Good Health Plus, Inc., 743 S.W.2d 373 (Tex. A pp.-San A ntonio 1987, no writ); see also Donivan v. Community Health Plan, N o. 882-95 (N.Y. Supreme Ct., A lbany Co., J une 14,1996 ) (holding $\S 4410.1$ of N.Y. Public H ealth Law bars medical negligence claims against H M O s). 
In part because these decisions could be reversed only by legislation, in early 1997 Texas became the first state to pass a law specifically subjecting managed care organizations to liability. ${ }^{88}$ U nder the Texas law, a health insurance carrier, health maintenance organization, or other managed care entity has a duty to exercise ordinary care when making health care treatment decisions, and is liable for harm to an enrollee proximately caused by its failure to exercise ordinary care.89 However, the Texas enactment is ambiguous in certain respects. For example, the statute requires independent review of claims prior to suit, paralleling notice procedures for medical malpractice suits against physicians under existing state law, but arguably exempts managed care claims from other limitations that Texas imposes on conventional malpractice suits. ${ }^{90}$ It also seems possible under the new law to sue physicians and traditional health facilities under one set of legal claims, and managed care organizations under another set, though both arise from the same activities.

Similar legislation is under consideration elsewhere. ${ }^{91} \mathrm{M}$ issouri recently enacted a sweeping managed care reform law, including a provision subjecting HMOs to liability. ${ }^{92}$ Florida passed a managed care malpractice bill in 1996 , but it was vetoed by the governor. ${ }^{93}$ New Y ork's version passed the state assembly but was delayed in the senate; proponents plan to reintroduce it in 1998. ${ }^{94}$ Connecticut's 1997 omnibus managed care consumer protection law included provisions on liability, but they were deleted before passage. ${ }^{95}$ Other states have bills pending. ${ }^{96}$

On the other hand, the lower court in Berlin was not persuaded that Illinois's longstanding imposition of malpractice liability on hospitals implied the unenforceability of that state's seemingly moribund corporate practice prohibition. See Berlin, 664 N.E.2d, at 344; cf. Darling v. Charleston Community M em'I H osp., 211 N.E.2d 253 (III. 1965). A particularly ironic aspect of the apparently contradictory outcomes of the two Illinois cases is that the losing party in Darling was the corporate predecessor of the losing party in B erlin.

88. See S. 386, 75th Leg. (Tex. 1997).

89. Id. § 88.002 .

90. See Medical Liability and Insurance Improvement A ct of Texas, TEX. REV. CIV. STA T. A NN., A rt. 4590i (West 1997). Important provisions that probably do not apply to suits against managed care entities include shortened statutes of limitations and a cap on wrongful death damages.

91. See Leigh Page, Texas E yes M easure to Extend L iability to M anaged Care, A M. MED. NEWS, A pr. 14, 1997, at 4.

92. See H.R. 335, 89th G.A., 1st Reg. Sess. (M o. 1997) (codified at Mo. Rev. Stat. §§ 538.205538.30) (adding HMOs to the definition of "health care providers" that may be sued for medical malpractice).

93. See H.R. 1853, 1996 R eg. Sess. (Fla. 1996) (vetoed M ay 28, 1996).

94. See A.B. 1816, S. 2544, 220th L eg. Sess. (N.Y . 1997) (requiring managed care organizations to exercise reasonable care when making decisions that affect diagnosis, care, or treatment of members).

95. See 1997 Conn. A cts 99 (R eg. Sess.).

96. See H.R. 314, S. 296, 1997 R eg. Sess. (A la. 1997) (imposing duty of ordinary care and making managed care plans liable for medical decisions of employees, agents, and representatives); S. 211, 144th Leg. (G a. 1997) (requiring ordinary diligence in the administration of health benefits); A.B. 3188 , 207th L eg. (N.J . 1997) (imposing duty of ordinary care for decisions to delay, reduce, or deny medical treatment that adversely affect a patient's health); H .R . 677, 122d L eg. (O hio 1998) (imposing duty of ordinary care).

California, Colorado, M aryland, and M aine also are expected to debate liability initiatives in 1998. 
These laws and bills fall short of "ideal" enterprise liability in two respects. First, they lack the administrative oversight of dispute resolution necessary to improve access to the malpractice system as a compensatory mechanism. ${ }^{97}$ Second, they neglect measures to discourage frivolous lawsuits and limit excessive awards, measures which are needed to provide balanced incentives for quality improvement. ${ }^{98} \mathrm{~A}$ dmittedly, the advisability of such restrictions is a close question. In fee-for-service practice, caps on non-economic damages have selectively penalized the most seriously injured plaintiffs, especially during periods of high medical inflation when lump-sum awards for future medical expenses often proved inadequate. On the other hand, institutional defendants are much more vulnerable than individual physicians to large punitive damages whose social utility is doubtful.

\section{$\mathrm{V}$}

\section{Conceptual Fla WSin The CuRREnT MOVEMENT}

A lthough the growth of managed care has obviated many of the original objections to enterprise liability, new problems-some legal and some structural-have arisen as barriers to the successful implementation of an industrial model for addressing medical errors. These include strained judicial interpretations of the Employee Retirement Income Security A ct of 1974 ("ERISA"), the unpredictable applicability of existing tort reform laws to managed care liability, unexpected regulatory developments affecting arbitration and alternative dispute resolution, the proliferation of undifferentiated managed care networks instead of truly integrated health systems, continued public fixation on individual rather than institutional quality improvement, and inflexibility in the market for mal practice liability insurance.

See, e.g., California Managed health Care improvement task Force, improving the DELIVERY OF CARE AND A CCOUNTA BILITY IN THE PRACTICE OF MEDICINE, at 8 (1997) (available at <http://chipp.cahwnet.gov/mctf/PA PE R S.htm> (visited Feb. 23, 1998)) (suggesting that the California legislature pass legislation providing that "entities which contribute to medical decisions affecting health care, including health plans, hospitals, medical groups, [Independent Practice A ssociations, Third Party A dministrators, and Professional Service A ssociations], may be held liable for damages for harm to a person caused by medical decisions directly contributed to by that entity"). The Task Force later backed away from this recommendation and was unable to reach an alternative consensus. See Laura Mahoney, Push for L egislation Called Likely Following Task Force's M anaged Care Report, BNA HEALTH L. REP., J an. 8, 1998, at 68-69. Nonetheless, bills introduced in California during 1997 included measures to expand the statutory definition of medical practice to include medical necessity determinations, see A.B. 794, 1997-98 R eg. Sess. (Cal. 1997), and to create a new cause of action for failure by a health plan to exercise ordinary care, see A .B. 977, 1997-98 R eg. Sess. (Cal. 1997).

97. Several states that are adopting or considering managed care liability laws are also requiring external appeals of adverse coverage determinations. See 1997 Conn. A cts $99 \S 20$ (Reg, Sess.). H owever, these laws and regulations do not address medical malpractice, and neither aid in identifying medical injuries nor help resolve related disputes.

98. The political viability of caps in managed care liability laws is uncertain. On one hand, most current state legislation has been drafted by consumer advocates and the trial bar. On the other hand, passage of these laws frequently depends on their being palatable to organized medicine and the insurance industry. 


\section{A. ERISA}

In the absence of federal legislation establishing enterprise liability, state law claims against managed care organizations typically run up against ERISA. 99 ERISA broadly preempts state laws that "relate to" employee benefit plans, but does not substitute a clear federal regulatory scheme. ${ }^{100}$ ERISA preemption of personal injury claims is significant both individually and in the aggregate. A pproximately sixty percent of non-elderly A mericans receive health coverage through their employers, with the vast majority of these benefit plans qualified under E RISA. ${ }^{101}$

ERISA applies not only to employers themselves, but also to a range of insurance and administrative entities to which employers delegate responsibility. ${ }^{102}$ Because of ERISA, persons injured by the conduct of managed care organizations may be unable to bring causes of action such as wrongful death, professional negligence, intentional infliction of emotional distress, or bad faith breach of insurance contract.103 If they decide to sue, they must do so in federal court, possibly without the benefit of a jury trial. 104 M ost importantly, their maximum potential recovery is the value of the health care benefit wrongfully denied plus attorneys fees in many cases. ${ }^{105}$ Neither extracontractual compensatory nor punitive damages may be awarded. 106

Because of ERISA's strict limitations on claims and damages, lawsuits involving a large subset of injured patients are seldom brought. The public policy implications of this depend on one's overall view of personal injury

99. See 29 U.S.C. $\S \S 1101-1461$ (1994). ERISA preemption of personal injury claims has prompted a spate of recent scholarship. See, e.g., David H. Sculnick, HMO Liability and ERISA Preemption for M edical M alpractice, A BA HEA LTH LA W., Spring 1996, at 8.

100. 29 U .S.C. § 1144(a) (1994). Commentators generally refer to this phenomenon as the "E RISA vacuum." See A Ian I. Widiss \& Lawrence O. Gostin, What's Wrong with the ERISA "Vacuum" ?: The Case A gainst Unrestricted Freedom for Employers to Terminate $E$ mployee $H$ ealth Care Plans and to D ecide What Coverage Is to B e Provided When R isk Retention Plans A re E stablished for Health Care, 41 DRAKE L. REV. 635 (1992).

101. See J ohn H olahan et al., A Shifting Picture of Health Insurance Coverage, HEALTH A FF., Fall 1995 , at 253.

102. See 29 U.S.C. § 1103(21) (1994) (defining fiduciary as a "person who exercises any discretionary authority or discretionary control in the management of the plan or the management or disposition of the plan's assets").

103. See 29 U .S.C. § 1144 (1994); Pilot L ife Ins. Co. v. D edeaux, 481 U .S. 41 (1987).

104. See Blau v. Del M onte Corp., 748 F.2d 1348 (9th Cir. 1985); In re V orpahl, 695 F.2d 318 (8th Cir. 1982); Calamia v. Spivey, 632 F.2d 1235 (5th Cir. 1980); Wardle v. Central States, 627 F.2d 820 (7th Cir. 1980).

105. See 29 U.S.C. $\S \S 1132(a),(g)(1)$ (1994) (stating that beneficiary may "recover benefits due to him under the terms of his plan, ... enforce his rights under the terms of the plan, or ... clarify his rights to future benefits under the terms of the plan"; and that the court may award a "reasonable attorney's fee and costs of action to either party").

106. See M ertens V. Hewitt A ssocs., 508 U .S. 248, 260 (1993) (stating that provision in § 502(a) of ERISA allowing "appropriate equitable relief" does not permit award of money damages); M assachusetts M ut. Life Ins. Co. v. R ussell, 473 U.S. 134, 148 (1985) (holding that extracontractual damages are not available in $\S 409$ (a) action). Lost wages, however, may be recoverable as equitable relief. See H emelt v. U nited States, 122 F.3d 204, 209-10 (4th Cir. 1997) (stating that "[b]y holding that ERISA section 502(a)(3) only permits equitable relief, of which lost wages and other economic harms are a major component, $M$ ertens reinforces our conclusion that the settlement payments at issue here are wages"). 
litigation in health care. To the extent that medical litigation is hopelessly flawed as a compensatory mechanism, ERISA preemption undoubtedly conserves administrative expense. However, any potential deterrent effect of litigation on managed care organizations is lost as well. ${ }^{107}$ Even more problematic is the fact that similarly situated patients in terms of the circumstances and extent of their injuries have vastly different legal rights and remedies.

Prior to 1995, courts evaluating claims against managed care organizations for medical injuries were effectively handcuffed by what was then thought to be ERISA's uniquely broad preemptive reach. ${ }^{108}$ In ruling against a very sympathetic plaintiff in Corcoran v. U nited H ealthcare, Inc., ${ }^{109}$ for example, the Fifth Circuit Court of A ppeals resigned itself to the fact that "[t]he result ERISA compels us to reach means that the Corcorans have no remedy, state or federal, for what may have been a serious mistake." 110

A mong other things, judicial solidarity upholding preemption induced plaintiffs' lawyers to look for more subtle approaches that did not constitute frontal assaults on ERISA. O ne strategy has been to identify causes of action under federal laws that coexist with ERISA and that either apply more lenient standards for liability or allow more generous remedies. For example, lawsuits based on benefits determinations that involve hospitals may include claims for relief under the Emergency Medical Treatment and A ctive Labor Act ("EMTALA"),111 which was enacted to prevent "patient dumping" for economic reasons. ${ }^{112}$ In addition, suits for denials of benefits have been brought alleging gender-based discrimination under Title VII of the Civil Rights A ct of 1964 or disability-based discrimination under the A mericans with D isabilities A ct ("ADA").113 Some of these cases have generated rulings whose breadth calls into question efforts to design clinically cost-effective benefits. In

107. Defensive medicine seems less a concern for managed care organizations because, unlike physicians receiving fee-for-service payment, they generally have strong financial incentives not to overtreat.

108. See Franchise Tax Bd. v. Construction Laborers V acation Trust., 463 U .S. 1, 25 n.26 (1983) (discussing ERISA 's "virtually unique preemption provision"), quoted in Shaw v. Delta A irlines, Inc., 463 U .S. 85,98 n.15 (1983).

109. 965 F.2d 1321 (5th Cir. 1992).

110. Corcoran, 965 F.2d at 1338. D espite the softening of preemption discussed below, courts still find themselves in ethically unsatisfactory situations because of ERISA. See A ndrews-Clarke v. Travelers Ins. Co., N 0. 97-10191-WG Y, 1997 U.S. D ist. LEXIS 17390, at *11-12 (D. M ass. O ct. 30, 1997) (dismissing claim, but commenting that "under traditional notions of justice, the harms alleged... should entitle [the plaintiff] to some legal remedy," and calling the outcome required by ERISA "ridiculous").

111. See 42 U .S.C. § 1395dd (1994).

112. See, e.g., Tolton v. A merican Biodyne, Inc., 48 F.3d 937 (6th Cir. 1995) (involving suicide of patient allegedly denied treatment for mental illness and substance abuse).

113. A Title VII plaintiff must first file a complaint with the Equal Employment Opportunity Commission ("EEOC"). If the EEOC decides that there is "reasonable cause" to believe the allegation of discrimination is true, it may prosecute the case itself. If it decides not to prosecute the case, it issues a "right-to-sue letter" entitling the plaintiff to pursue the case privately. See 42 U .S.C. § 2000e-5 (1994); 29 C.F.R. § 1601.28 (1997). 
H enderson v. B odine A luminum Corp. ${ }^{114}$ for example, a federal appeals court suggested that the A DA prohibits employers from covering a given treatment for some underlying conditions but not for others. ${ }^{115}$

Moreover, the effect of ERISA on managed care liability is currently in flux. ${ }^{116}$ Courts are finding new meaning in ERISA 's existing provisions and Congress is considering significant amendments to liberalize claims and recoveries for injured patients. Courts are also pushing the limits of recent Supreme Court decisions, concluding that medical malpractice is beyond the direct preemptive scope of ERISA and assessing liability against managed care organizations. 117 Unfortunately, this liberalization of ER ISA preemption does not necessarily equate to a rational application of enterprise liability principles.

1. Distinguishing Coverage and Care. ERISA jurisprudence in the medical arena is ultimately about drawing an increasingly elusive line between coverage and care. Because of ERISA's preemptive reach, if a patient's predicament is deemed to arise from a benefit determination, little legal recourse may be available. If merely a treatment decision is implicated, rights and remedies may be far more generous. However, the pegs in actual disputes seldom fit neatly into these holes. Consequently, although courts sometimes achieve rough justice in individual cases by hammering away at the distinction, their

114. 70 F.3d 958 (8th Cir. 1995).

115. The court concluded that "if the evidence shows that a given treatment is non-experimental ... and the plan provides the treatment for other conditions directly comparable to the one at issue, the denial of treatment arguably violates the A DA." Id. at 960. This language stands in contrast to an influential pre-A D A ruling, M cGann v. H\&H M usic C0., 946 F.2d 401 (5th Cir. 1991), which upheld an ERISA plan's decision to convert from insured to self-insured status in order to substantially restrict coverage for A IDS. Other courts have declined to apply the ADA to coverage decisions. See Parker v. M etropolitan Life Ins. Co., 121 F.3d 1006 (6th Cir. 1997) (en banc) (holding that the A D A does not prohibit an employer from adopting a long-term disability plan containing longer benefits for employees who become disabled due to physical illness than for those who become disabled due to mental illness); cf. Krauel v. I owa Methodist Med. Ctr., 95 F.3d 674 (8th Cir. 1996) (stating that exclusion from coverage of fertility treatments does not violate the ADA because infertility is not a covered disability). However, the Supreme Court recently held that even nonvested benefits such as health coverage are subject to the prohibition on discrimination contained in $\S 510$ of ERISA, as long as the plaintiff can prove unlawful intent. See Inter-M odal Rail E mployees A ss'n v. A tchison, Topeka \& Santa Fe R y. Co., 117 S. Ct. 1513 (1997); see also M axwell J. M ehlman et al., When D o H ealth Care Decisions Discriminate A gainst Persons with Disabilities?, 22 J. HEALTH, POL., POL'Y \& L. 1385 (1997); David Orentlicher, Destructuring Disability: Rationing of Health Care and Unfair D iscrimination A gainst the Sick, 31 H A R V. C.R -C.L. L. R E V. 49 (1996).

116. Nonetheless, ERISA preemption has continued vitality with respect to other state legislation affecting managed care, such as any-willing-provider laws. See CIGNA Healthplan v. L ouisiana ex rel. leyoub, 82 F.3d 642 (5th Cir. 1996) (holding that any-willing-provider law is preempted). The direction of ERISA preemption regarding claims under more general fair trade practices laws is less clear. See Napoletano v. CIG NA H ealthcare, Inc., 680 A.2d 127 (Conn. 1996) (stating that state law claims by terminated providers and their patients are not preempted); M argaret G. Farrell, ERISA Preemption and Regulation of $\mathrm{M}$ anaged $\mathrm{H}$ ealth $\mathrm{C}$ are: The $\mathrm{C}$ ase for $\mathrm{M}$ anaged Federalism, $23 \mathrm{~A}$ M. J .L . \& MED. 251 (1997).

117. On the other hand, the recent Texas enactment imposing malpractice liability on managed care organizations has been challenged under ERISA, and similar cases can be expected elsewhere See Corporate H ealth Ins. v. Texas D ept. of Ins., N o. H -97-2072 (U .S. Dist. Ct., H ouston, Tex. 1997); Linda O. Prager, A etna Challenges Texas L aw Lifting HMOS' ERISA Shield, A M. MED. NEWS, July 21,1997 , at 1, 25. Of course, if the law in fact purported to do what the article's headline claims, A etna's challenge undoubtedly would succeed. 
increasingly strained reasoning is unlikely to offer a long-term solution to the problem of medical injury in managed care.

When insurance organizations were distinct from health care providers, it was easy enough to distinguish the decision to deliver a service from the decision to pay for it. The former was potentially a medical malpractice case; the latter an insurance coverage case or, given ERISA's broad preemptive scope and restrictive remedies, no case at all.

$M$ anaged care has challenged these assumptions. Today, it is difficult to separate the payment from the service function in health coverage. Because managed care requires preauthorization for hospitalization, surgery, and other expensive services, denial of payment is often tantamount to denial of care. ${ }^{118}$ Vertical integration-whether through common ownership or contractual affiliation-further blurs the distinction. Closed-panel HMOs are virtually useless to patients who are denied benefits, while contractual affiliations between insurers and providers may result in situations where coverage considerations influence clinical recommendations by individual physicians. ${ }^{119}$ Gatekeeping restrictions on specialist referrals arguably compound many of these problems. ${ }^{120}$

Not only are whole organizations functionally integrated, but individual participants often perform several roles. ${ }^{121}$ For example, insurance regulations and professional conventions have led insurers to place considerable weight on contractual exclusions for "experimental," "investigational," or "medically unnecessary" treatment. These are largely clinical judgments requiring professional expertise.122 At the same time, medical groups, by subcontract

118. E ven in fee-for-service practice, courts evaluated payment cases with the understanding that, in the less-than-universal A merican health care system, failure to finance care sometimes meant failure to receive it.

119. See deM eurers v. H ealth N et, N o. 239338 (R iverside C ty. Super. Ct., D ec. 13, 1995) (approving arbitration award of $\$ 1.3$ million given evidence that HMO had pressured physician to change recommendation regarding treatment for breast cancer). Explicit "gag clauses" in managed care contracts, though probably seldom invoked in practice to restrict communication of clinical information or prohibit disclosure of non-covered alternatives, appear to have met their demise through legislation or voluntary action under its threat. See U.S. GENERAL A CCOUNTING OFFICE, ManAged CARE: EXPLICIT Gag CLAUSES NOt FOUND IN HMO CONTRACTS, BUt PhySICIAN CONCERNS REMAIN, (1997); see also CAL. BuS. \& PROF. CODE § 1056.1 (West 1997); GA. CODE A NN. § 33-20A -7 (1997); I ND. CODE § 27-13-15-1(a) (1997); ME. REV. STA T. A NN. tit. 24-A , § 4303(3) (W est 1997); R.I. GEN. L A WS § 23-17.13-3 (1996); W A SH. R E V. CODE § 48.43 .075 (1997).

120. See supra text accompanying note 78. Point-of-service plans and broad networks of providers have alleviated this concern to some degree, as has the decline of gatekeeping.

121. A fascinating fictional dialogue exploring the tension between individual and group health management can be found in David M. Eddy, Broadening the Responsibilities of Practitioners: The Team A pproach, 269 J A M A 1849 (1993).

122. One legislative trend is to subject these decisions to independent professional review. See A.B. 1663, 1995-96 Reg. Sess. (Cal. 1996) (codified as amended at CAL. HEALTH \& SAFETY CODE $\S$ 1370.4 (West 1997), CAL. INS. CODE § 10145.3 (West 1997)). Notice that it is easier to impose an independent review requirement on medical necessity judgments than on utilization management decisions as a whole, because many of the latter have contractual rather than purely clinical determinants. See 1997 Conn. A cts $99 \S 20$ (R eg. Sess.) (providing for two-stage review by insurance commissioner and medical experts); see also S. 5489, 220th Leg. (N.Y. 1997) (establishing independent treatment review organizations for the purpose of making recommendations regarding health insurance coverage in certain instances). 
from insurers, sometimes rule on the availability of services under subscriber policies. ${ }^{123}$

The importance of ERISA to liability exposure is likely to bring many of these tough cases to court, especially since ERISA is a potential shield for individual physicians if they qualify as "plan fiduciaries." However, plan fiduciaries have obligations to beneficiaries that may not be congruent with physicians' usual duties to patients. In particular, disclosure of conflicts of interest under ERISA may be stricter than under state informed consent laws. ${ }^{124}$

2. Reinterpreting ERISA A fter Travelers. In 1995, the U nited States Supreme Court decided New York State Conference of Blue Cross \& Blue Shield Plans v. Travelers Ins. Co.125 The Court held that N ew Y ork's hospital surcharge program had merely an indirect effect on employer costs that was not sufficiently substantial to relate to ERISA plans and therefore was not preempted. 126 This was a dramatic departure from prior case law. ${ }^{127}$ Lower courts quickly took Travelers as an indication that ERISA preemption was no longer absolute, even in individual personal injury cases that were very different in posture and character from state legislative efforts to impose substantive regulations on ER ISA plans. ${ }^{128}$

123. Theoretically, physicians performing intermediate functions between coverage and care risk unpredictable liability exposure. On the one hand, benefits responsibilities delegated under ERISA may allow physicians to invoke ERISA preemption. On the other hand, liability for nonclinical tasks may be excluded from physicians' malpractice coverage and may not be subject to state law limits on recovery.

124. See infra text accompanying note 199.

125. 514 U .S. 645 (1995).

126. A $n$ interesting question raised by the Travelers decision is that, apart from the formal difference of their application to premiums rather than hospital charges, state premium taxes also exert purely economic effects of similar magnitudes (and do so for the similar purpose of supporting uncompensated care). Y et such laws clearly are preempted by ERISA as applied to self-funded employers. O ne wonders if the flight of employers toward self-insurance (coupled with the rapid growth of stop-loss insurance) persuaded the Court to rethink its position.

Travelers also lists three categories of state laws that generally remain preempted: mandated benefits, mandated administrative requirements such as data reporting, and alternative enforcement mechanisms. See Travelers, 514 U .S. at 658-62. The reference to enforcement derives from wrongful termination laws, not causes of action for medical malpractice. See Ingersoll-R and Co. v. M cClendon, 498 U.S. 133 (1990). Nonetheless, courts construing personal injury claims as not preempted by ERISA must step carefully around this third group.

127. Prior health care cases involving state mandated benefits and other consumer protection or uncompensated care funding strategies generally were litigated over ERISA's insurance savings clause. See, e.g., M etropolitan Life Ins. Co. v. Massachusetts, 471 U.S. 724 (1985) (holding that mandated benefit law is preempted only as applied to self-insured employers). Travelers cut the inquiry short by avoiding even a threshold finding of relatedness. See also DeBuono v. NY SA -ILA Med. and Clinical Servs. Fund, 117 S. Ct. 1747 (1997) (finding that surcharge is not preempted as applied to treatment centers owned and operated by E RISA plan).

128. The Supreme Court's decision in Travelers also took pressure off Congress to amend E RISA by giving courts additional flexibility in tough cases. Despite the difficulties caused by ERISA preemption, the law was a political can of worms that Congress had been reluctant to reopen. A the same time, the lower court decisions in the case had put New Y ork State's hospitals in financial jeopardy. See Travelers Ins. Co. v. Cuomo, 14 F.3d 708 (2d Cir. 1994), aff'g and rev'g in part 813 F. Supp. 996 (S.D.N.Y . 1993). W hile the case was on certiorari, Sen. D aniel Patrick M oynihan came to 
D ukes v. U.S. H ealthcare, Inc., ${ }^{129}$ a 1995 Third Circuit ruling, is frequently cited for the proposition that, after Travelers, medical malpractice claims against managed care organizations are not necessarily preempted by ERISA . 130 The case arose from the alleged negligent failure to diagnose and treat high blood sugar, which led to a patient's death. Claims were brought against several physicians, two hospitals, and, under a theory of ostensible agency for the actions of the physicians, the decedent's H M O. U.S. H ealthcare removed the case to federal court, and requested dismissal of the claims against it as preempted by E RISA. H owever, the federal district court refused to hear the case and returned it to state court for further proceedings, citing several differences between the Dukes's allegations and a claim for benefits under ERISA.

In reaching its conclusion, the court distinguished the existence of benefits, which it considered within the purview of the Dukes's ERISA plan, from the quality of benefits, which it did not. Because the participating doctor's alleged malpractice was an issue of quality, the court ruled that a suit against U.S. Healthcare based on apparent agency was not a claim under the Dukes's employee benefit plan and therefore was not completely preempted. ${ }^{131}$

A Ithough this reasoning allowed the court to avoid curtailing the remedies potentially available to the plaintiff, it is less generalizable than is usually recognized. The court did not regard quality as an inappropriate subject for an ERISA plan, but held only that the Dukes's plan failed to address it. A s the court observed, "we also recognize the possibility that an ERISA plan may describe a benefit in terms that can accurately be described as related to the quality of the service." 132 Presumably, if the plan document had specified the standard of care, a suit based on lack of compliance with the plan would be a

the rescue. In a stunning display of naked political power, a provision appeared in the annual budget reconciliation bill revoking the tax deductibility of health benefits for $\mathrm{New} Y$ ork employers who refused to pay the supposedly unlawful state surcharges. See $O$ mnibus Budget Reconciliation A ct, Pub. L. No. 103-66, § 13442, 107 Stat. 312, 568 (1993) (codified as amended at 26 U.S.C. § 162(n) (1994)).

129. 57 F.3d 350 (3d Cir. 1995).

130. See Darryl van D uch, N ew D anger for HMOs, NAT'L L.J., M ay 13, 1996, at A 1 (observing that the Dukes trend constitutes "judicial enterprise liability"). The actual holding of the case is more limited. The federal court to which the case had been removed found only that removal was improper because the Dukes's claim was not one for redress under ERISA itself. It was therefore not "completely preempted," meaning that it did not present a federal question subject under ERISA to exclusive federal jurisdiction. The judge sent the case back to the state court to decide whether state law claims were in fact preempted which, like the Corcorans, would leave the D ukes without a remedy. This task may be performed by both state and federal courts.

131. A t least one court appears to have used the distinction between quality and quantity of benefits to deny complete preemption even for the direct actions of the managed care organization in selecting physicians and instituting utilization review policies. See K ampmeier v. Sacred H eart Hosp., N o. 957816, 1996 U.S. D ist. LEXIS 5739 (E.D. Pa. M ay 1, 1996); see also Pappas v. A sbel, 675 A .2d 711, 716 (Pa. Super. Ct.), appeal granted by 686 A .2d 1312 (Pa. 1996) (holding there was no preemption of claim that HMO negligently delayed authorizing patient transfer because claims at issue had no connection to benefit scheme Congress sought to protect through ERISA).

132. See D ukes, 57 F.3d at 358. 
claim under ERISA and would be preempted. ${ }^{133}$ Whether anything in ERISA itself precludes such a provision is an unanswered question, but the basic holding in M CG ann v. $\mathrm{H} \& \mathrm{H}$ M usic Co. suggests not. ${ }^{134}$

Since the Dukes case, several courts have held that if a managed care organization's liability is derivative of a physician's- by virtue of respondeat superior, ostensible agency, or similar doctrines-the same degree of preemption should apply to each defendant. ${ }^{135}$ Therefore, these courts have concluded that suits against managed care organizations for acts of malpractice committed by participating physicians either are not claims under ERISA removable to federal court or do not "relate to" an employee benefit plan at all. 136

This conclusion undoubtedly serves the interests of injured patients and their attorneys. As managed care grows, even unsystematic incidents of possible malpractice will be linkable through association with umbrella organizations such as insurers. These organizations will frequently be large, well-capitalized entities with marginal reputations among either the public or the medical community-in other words, ideal deep pockets. Moreover, in today's competitive environment, aggressive advertising and marketing practices usually will provide enough evidence of apparent agency to survive summary judgment. 137

U nfortunately, favoring vicarious over direct claims is somewhat illogical. In the absence of ERISA, malpractice claims against managed care

133. For a discussion of private contracting regarding the standard of care, see $\mathrm{R}$ ichard $\mathrm{A}$. E pstein, $M$ edical M alpractice, Imperfect Information, and the Contractual Foundation for M edical Services, 49 LA W \& CONTEM P. PROBS. 201 (Spring 1986) (discussing contractual standards of liability).

134. See M CG ann., 946 F.2d 401. E ven in the absence of benefit language setting forth the standard of care, the Dukes approach is problematic. For example, the court qualified its dichotomy between existence and quality with the comment that circumstances might arise in which the quality of care was so poor as to constitute constructive denial of a benefit. See Dukes, 57 F.3d at 358. However, this would have the counterintuitive effect of immunizing the plan from damages when quality was abysmal, while exposing it when quality was merely substandard.

135. There are no reported cases holding that a malpractice claim against a physician is preempted merely because the patient received employer-sponsored health coverage. A s physicians assume more responsibility for managing the health of populations, often under risk-bearing contracts, physicians may both desire and deserve to assert rights under ERISA.

136. See Rice v. Panchal, 65 F.3d 637 (7th Cir. 1995) (holding vicarious liability claim against insurer for actions of preferred provider not completely preempted); Pacificare Inc. v. Burrage, 59 F.3d 151 (10th Cir. 1995) (approving remand to state court of vicarious liability claim against H M O for malpractice of primary care physician); L ancaster v. Kaiser Found. Health Plan, Inc., 958 F. Supp. 1137 (E.D. Va. 1997) (holding vicarious liability claim for negligent care prompted by practice guidelines and cost standards not preempted); E delen v. O sterman, 943 F. Supp. 75, 76 (D.D.C. 1996) (stating that malpractice claim involving physician employed by $\mathrm{H}$ M O has "too tenuous a relationship to employee benefit plan" to be preempted); H oward v. Sasson, N o. CIV .A .95-0068, 1995 WL 581960 (E.D.Pa. O ct. 3, 1995) (stating that vicarious liability claim against $\mathrm{H}$ M O for actions of pediatrician is not removable to federal court). But see Jass v. Prudential Health Care Plan, 88 F.3d 1482 (7th Cir. 1996) (holding that, because determining the relationship between defendant HMO and participating surgeon required examining the employee benefit plan, a vicarious liability claim against the H M O based on the surgeon's negligence was completely preempted).

137. Some Blue Cross plans are riding the current wave of suspicion regarding managed care by advertising that "[w]e want to be your health plan, not your doctor." However, marketing representations as to the quality of the doctors affiliated with health plans are probably inevitable. 
organizations typically would include allegations of direct malfeasance such as inadequate credentialing of participating physicians, faulty oversight of referral patterns, imposition of substandard practice guidelines, and negligent utilization review. Under prevailing law since Dukes, however, ERISA will generally preempt these direct claims while allowing vicarious claims based on a far lower degree of moral culpability to proceed. ${ }^{138}$

Beyond the ethical absurdity of this distinction, there will be situations where factually separating direct and vicarious claims is impossible. Does it make sense to allow a patient injured by a bad doctor in a bargain-basement network to recover damages from the organization that selected the doctor on the theory that the doctor was bad-but not on the theory that the selection was bad? What about an informed consent claim based on failure to disclose financial incentives that influence care decisions? ${ }^{139}$ Can a health plan logically be held vicariously liable for the effect on physician-patient communications of its compensation structure when it could not be held directly liable for the compensation structure itself?

A few cases, including Dukes, have suggested that even direct claims may not be preempted if they involve allegations of negligent selection of physicians or negligent imposition of financial incentives, rather than negligent utilization review. ${ }^{140}$ These decisions typically reason that inquiries into the contractual relationship between ERISA plans and providers do not require examination of the plan document, and therefore are not claims under ERISA. There are two difficulties with this logic. First, ERISA 's fiduciary duty requirements probably require disclosure of financial incentives and other aspects of the

138. States are pushing the envelope to challenge benefit determinations as well. For example, professional licensing boards in many states are asserting disciplinary authority over medical directors of health plans and other health professionals employed by managed care organizations in administrative capacities. Courts are divided as to the legitimacy of this approach, and it remains unclear whether such actions are preempted by ERISA. In the first case to be litigated, an A rizona appeals court upheld the issuance of an "advisory letter of concern" to the medical director of a large HMO for wrongfully denying coverage for laparoscopic cholecystectomy. See M urphy v. A rizona Bd. of M ed. Exam'rs, 949 P.2d 530 (A riz. Ct. A pp. 1997). But see M orris v. District of Columbia Bd. of Med., 701 A.2d 364 (D.C. Ct. A pp. 1997) (concluding that Blue Cross medical director was not "practicing medicine" so as to require local licensure).

139. See M oore v. R egents of the U niv. of Cal., 793 P.2d 479, 483 (Cal. 1990) (holding that consent for medical procedure was impaired by physician's financial interest in research from procedure); D.A.B. v. B rown, 570 N.W.2d 168 (M inn. Ct. A pp. 1997) (holding that claim that physicians failed to disclose payments from drug company to prescribe Protropin was untimely because it should have been brought under informed consent law); see also J ury Rejects \$13.5 M illion L awsuit A gainst H M O, J OURNAL RECORD, Oct. 3, 1996, at 3 (describing Gross v. Prudential Health Care Plan, No. C) 9474267 (O kla. Cty. Ct. O ct. 1, 1996), denying summary judgment against U niversity of O klahoma professor who claimed his doctor and HMO tried to "maximize profits and bonuses by denying him" care). Construing informed consent this broadly is a departure from current law in many states, which limits the doctrine to invasive procedures and imposes strict standards of causation. See, e.g., N.Y . PUB. HEALTH LAW § 2805-d (M CK inney 1997).

140. See, e.g., Dukes, $57 \mathrm{~F} .3 \mathrm{~d}$ at 360-61 (stating that "only in a utilization-review role is an entity in a position to deny benefits due under an ERISA welfare plan"); O uellette v. Christ H osp., 942 F. Supp. 1160 (S.D. O hio 1996) (suit against health insurer alleging malpractice based on hospital financial incentives not completely preempted). 
plan-provider relationship. ${ }^{141}$ Second, any-willing-provider laws and other restrictions on provider contracting have been held to relate to employee benefit plans. ${ }^{142}$ A II in all, courts drawing a distinction between utilization review and other care management practices seem to be fixated on traditional models of insurer behavior, which begs the question of E RISA 's role in today's more complex health care system.

It is also worth considering how judicial decisions, if they continue to follow Dukes, might influence the structural choices and management strategies of managed care organizations. Certainly, as suggested by the Dukes court, managed care organizations may be able to insulate themselves from liability by specifying the standard of care in subscriber contracts. H owever, because a change of that magnitude would affect both health plan marketability and physician relations, one hardly would expect it to occur in the near future.

Nonetheless, other, less visible aspects of plan design and administration might be equally useful to risk management. Specifically, from a liability perspective, rule-based cost containment may be preferable to delegated authority using incentive compensation. For example, clinical practice parameters and strict prospective and concurrent utilization review seem more likely to remain shielded from liability by ERISA. Y et these tools may lead to worse quality care than incentive structures that allow physicians to continue their traditional practice of collegial consultation and to adhere to established ethical precepts.

\section{B. Tort R eform Laws}

Because the availability of damages is central to the cost and effectiveness of any tort system, another important question affecting both physicians performing care management tasks and managed care organizations is the extent to which state legislative limitations on medical malpractice suits will apply to managed care.143 When traditional tort reforms such as caps on noneconomic and punitive damages were enacted in the 1970s and 1980s, the determination of who was a "health care provider" and what constituted a "health care service" was straightforward. For example, California's M ICR A statute applies broadly to actions "arising out of the professional negligence of a health care provider," 144 but it does not govern negligence in nonprofessional services. ${ }^{145}$

Things are no longer as certain. The V irginia Supreme C ourt recently ruled

141. See infra text accompanying note 199.

142. See supra note 116. These holdings do not affect findings of "complete preemption" in tort cases, but nonetheless bear on whether pendant state claims are available.

143. See Thomas D. Price, $L$ iability for $N$ egligence in $M$ anaged $H$ ealth Care: Problems of Allocation and Prevention, CA L. HEA LTH L. NEWS, Spring 1992, at 8-10.

144. CA L. Civ. Proc. Code § 425.13(a) (West 1997); see also Central Pathology Serv. M ed. Clinic v. Superior Court, 832 P.2d 924, 926 (Cal. 1992) (holding that a negligent pap smear by a pathology laboratory was subject to MICRA).

145. See A ndrea N. v. Laurelwood Convalescent Hosp., 16 Cal. R ptr. 2d 894 (Cal. 1993) (holding that MICRA does not apply to damages for rape caused by poor security). 
that the state's $\$ 1$ million cap on damages does not protect a practice management corporation held jointly and severally liable with its physicianowner. ${ }^{146} \mathrm{E}$ ven issues as seemingly clear as hospital liability for a medical error may become muddied. Because theories of institutional quality improvement often focus on administrative processes, a medical injury might be construed as a failure of such processes rather than the result of faulty professional judgment. 147

Finally, personal injury suits are based increasingly on causes of action other than professional negligence. For example, courts have divided as to whether damages recovered from a hospital in a suit under EMTALA are subject to MICRA's $\$ 250,000$ cap. $^{148}$ Federal fraud and abuse laws also are being applied to situations involving patient injury. For instance, to the extent that liability under the federal False Claims A ct becomes applicable to poor quality managed care, state tort reforms would be entirely irrelevant to the calculation of damages. ${ }^{149}$

\section{D ispute R esolution}

A $n$ evolving area of law with important implications for enterprise liability relates to the enforceability and regulation of alternative dispute resolution systems. ${ }^{150}$ As discussed previously, part of the rationale for enacting enterprise liability in connection with national health care reform was the concurrent imposition of a system for registering grievances, coupled with a less adversarial and, one hopes, less costly forum for resolving disputes. 151 The goal of this design was to encourage a greater percentage of injuries to be reviewed than occurs in conventional litigation, without greater overall expense.

Traditionally, mandatory arbitration of personal injury claims was often held invalid as an impermissible legislative limitation on constitutional rights to due process and trial by jury, or because it had been imposed by medical providers in adhesion contracts. ${ }^{152}$ Over the past decades, however,

146. See Schwartz v. Brownlee, 482 S.E.2d 827 (V a. 1997). These decisions have implications for market organization. For example, even in states that allow the corporate practice of medicine, liability concerns lead most physician practice management companies to control individual practices by contract rather than by outright stock ownership. See PRICE WATERHOUSE, GIVING STRUCTURE AND BALANCE TO PPM TRANSACTIONS: GUIDE TO A CCOUNTING AND TAX ISSUES FUNDAMENTAL TO TODAY'SPPM TRANSACTIONS 5 (2d ed. 1997). However, contractual control is less efficient, and raises accounting, securities law, bankruptcy, and other issues.

147. See infra text accompanying notes 179-87.

148. Compare Barris v. County of Los A ngeles, 60 Cal. A pp. 4th 471, 483 (1997) (holding that "[s]tabilizing a patient is 'inextricably woven' with a hospital's professional duty") with J ackson v. East Bay H osp., 980 F. Supp. 1341 (N.D. Cal. 1997) (holding that E M TA LA is not a medical malpractice law subject to MICRA).

149. See 31 U .S.C. §§ 3729-33 (1994).

150. See Thomas B. M etzloff, A Iternative Dispute Resolution Strategies in Medical M alpractice, 9 A LASKA L. REV. 429 (1992).

151. See supra text accompanying notes $28-40$.

152. See Clark C. H avighurst, P rivate R eform of T ort-L aw D ogma: $M$ arket O pportunities and $L$ egal Obstacles, 49 LA W \& CONTEMP. PROBS. 143 (Spring 1986); see also Tunkl v. R egents of the U niv. of Cal., 383 P.2d 441, 443 (Cal. 1963). 
legislatures and courts have become more receptive to structured alternatives to litigation that provide cost-effective dispute resolution, even if they reduce access to the courts. For example, courts now generally uphold agreements to undergo binding arbitration as long as they comply with state statutory requirements. ${ }^{153}$ Consequently, managed care organizations-particularly closed-panel entities that acknowledge their influence on medical decisionsincreasingly include in their insurance contracts arbitration provisions for both insurance coverage and medical malpractice cases. ${ }^{154}$

With managed care growing rapidly, these practices are attracting regulatory scrutiny. M ost states, and the federal government under M edicare, have recently adopted regulations for the handling of coverage disputes between managed care organizations and their subscribers. ${ }^{155}$ Several such laws require advisory or binding review by independent entities. ${ }^{156}$ The effect of this trend on dispute resolution for medical malpractice is uncertain. Independent review arguably reduces bias; however, it also imposes additional costs and limits the ability of managed care organizations to construct optimal internal processes.

Courts also are addressing dispute resolution, most frequently in cases where consumers challenge the legality or applicability of arbitration clauses. For example, in Engalla v. Permanente Medical Group,157 the California Supreme Court ruled that Kaiser Permanente's failure to comply with the promised terms of arbitration might allow the plaintiff to avoid mandatory arbitration of his malpractice suit. ${ }^{158} \mathrm{~A}$ t the same time, however, the California

153. See M orris v. M etriyakool, 344 N.W .2d 736 (M ich. 1984).

154. K aiser's arbitration system is well known, but data on its operation have been closely guarded until recently. One might speculate that Kaiser pays more claims than its competitors (though in smaller amounts and with fewer transaction costs), which would not necessarily serve the organization's public relations interests regarding quality. A $n$ important effect of the E ngalla case is to open some of this information to litigants and, one hopes, researchers.

155. See M edicare A ppeals of Individual Claims, 62 Fed. R eg. 25844 (1997) (final rule); 1997 Conn. A cts $99 \S \S 18-23$ (R eg. Sess.). A s M edicare increases the percentage of its beneficiaries who are enrolled in managed care organizations, it will become the principal regulator of many managed care practices much as it now dominates fee-for-service care. See Grijalva v. Shalala, 946 F. Supp. 747 (D. A riz. 1996) (imposing governmental due process requirements on private health plans that enroll Medicare beneficiaries).

156. See supra note 122; see also ADVISORY COMMITTEE ON CONSUMER PROTECTION AND QUALITY IN THE HEALTH CARE INDUSTRY, CONSUMER BILL OF RIGHTS AND RESPONSIBILITIES: REPORT TO THE PRESIDENT OF THE UNITED STATES (1997) (available at <http://www.hcqualitycommission.gov/cborr/consbill.htm> (visited Feb. 23, 1998)) (recommending detailed internal appeals procedures, plus external review when treatment is denied as experimental, investigational, or not medically necessary).

157. 938 P.2d 903 (Cal. 1997).

158. Significantly, the court did not overturn K aiser's longstanding system of mandatory arbitration of malpractice and coverage disputes as written, only as applied to the plaintiff. N onetheless, the court allowed the plaintiff to introduce statistical evidence demonstrating Kaiser's systematic noncompliance. Kaiser recently announced plans to reconfigure its arbitration program in accordance with recommendations of a blue-ribbon panel established in the aftermath of E ngalla. A mong other measures, Kaiser will cede control of the arbitration process to an independent administrator, allow the use of a single neutral arbitrator, encourage early mediation, set explicit deadlines, and create a broad advisory panel. See THE BLUE RIBBON ADVISORY PANEL ON KAISER PERMANENTE Arbitration, the Kaiser Permanente arbitration System: A Review and 
court reiterated its general approval of mandatory arbitration for medical malpractice claims, a position also being taken by other states. ${ }^{159}$

Furthermore, recent U.S. Supreme Court jurisprudence may prove important to the arbitration of medical malpractice claims. In D octor's A ssocs., v. Casarotto, 160 the Court held that the Federal A rbitration A ct preempts state laws requiring arbitration agreements to contain elements such as bold-face type, mandatory disclosure, or rescissionary periods that are not applicable to other contracts. ${ }^{161}$ These features are common in consumer regulations governing arbitration in general and medical malpractice arbitration in particular. Consequently, states likely will be constrained as to how they may promote the efficient but fair resolution of disputes in managed care.

\section{Network Structure}

A s discussed above, proposals for systematic enterprise liability have been framed according to two views of the A merican health care system. ${ }^{162}$ In the first, hospitals were the focal point of health care delivery, as well as of iatrogenic injuries, and could consolidate claims brought against them and their medical staffs. In the second, distinct managed care health plans in competition with one another could balance cost and quality so as to optimize safety and compensation for their enrollees. The major problem today is that neither view reflects the way in which our managed health care system has actually evolved. Hospitals are increasingly peripheral to basic medical care, while health plans have fragmented into poorly differentiated and frequently overlapping networks of providers.

Based perhaps on a Kaiser prototype, the mental image of managed care has long been a closed-panel, staff- or group-model HMO that either employs or maintains exclusive contracts with its medical staff, which in turn treats patients in dedicated hospitals and clinics. Physicians in these settings tend to share a common culture and clinical philosophy, which is fostered by the selection process and reinforced by feedback and training from the parent organization. Traditional peer review and quality assurance activities are carried on easily within a closed-panel HMO's health facilities. It is thus

Recommenda tions for I mPROVEment (1998); Linda O. Prager, Kaiser Will Turn Arbitration Over to Neutral Party, A M. MED. NEWS, Feb. 2, 1998, at 3, 20.

159. See B uraczynski v. E yring, 919 S.W.2d 314 (Tenn. 1996); R obert J. Will, A rbitration of M edical Malpractice Claims: A Practical Update, ABA HEALTH LAWYER, Winter 1996, at 14 . But see Broughton v. CIGNA Healthplans, 65 Cal. R ptr. $2 d 558$ (Ct. A pp. 1997) (holding that plan may not compel arbitration of complaint under California Consumers Legal Remedies Act for deceptive advertising arising from medical injury because remedies under $A$ ct may not be waived).

160. 116 S. Ct. 1652 (1996). D espite its name, the case has nothing to do with medicine. Doctor's A ssociates franchises fast-food restaurants.

161. The Court in Casarotto overturned a M ontana law requiring notice of mandatory arbitration to appear in underlined capital letters on the first page of contracts. On the other hand, the Court held that general state law defenses to contract formation or enforcement, including unconscionability, may be applied to arbitration agreements notwithstanding the federal enactment. See id., at 1656-57.

162. See supra text accompanying notes 14-27. 
feasible to centralize grievance and dispute resolution processes, and to coordinate legal defenses. A lthough network-model organizations quickly emerged in the marketplace as competitive alternatives to closed-panel HMOS, advances in telecommunications and information processing suggested that this "virtual integration" would be able to capture the same synergies as physical integration, perhaps even at lower cost.

Theories of national health care reform based on managed competition bolstered this view of the consolidated, integrated health plan. Managed competition envisioned tightly controlled, "brand-name" organizations competing with one another based on price and quality of service.163 It was expected that these entities would procure the loyalty of select physicians through employment or long-term contract, inviting participation based on cost-effective practice style.164 Dissemination of carefully developed practice guidelines, coordination of treatment through primary care physician gatekeepers, and assembly of multidisciplinary care teams would add to uniformity. Moreover, hospitals and academic health centers promised to play major roles as anchors of integrated delivery systems, importing facility-based strategies for quality and accountability into managed care. A nticipating these trends, it seemed only logical for health plans to bear primary legal responsibility for adverse events caused by their medical management.

H owever, the reality of competition in managed care has not turned out to be discrete, competitive health plans with carefully selected provider panels. Instead, managed care in most markets consists of broad, overlapping contractual networks of physicians, hospitals, and other providers. 165 The umbrella managed care organization-bearing the brand name-performs primarily marketing, enrollment, and claims processing services. To the extent it even exists, "care management" consists of negotiating fees with providers, shifting risk to providers using financial incentives, and subcontracting utilization review to provider organizations or other entities.

There are several explanations for this trend. Most of all, the mantra of "choice" has become a dominant element in the political rhetoric of health care reform and, by extension, of managed care consumerism. ${ }^{166}$ A s a result, health

163. See A lain C. Enthoven, The History and Principles of M anaged Competition, HEALTH A FF., Supp. 1993, at 24.

164. Even this idealized vision, of course, recognized issues relating to risk-selection and other obstacles to constructive competition. See Sandra Shewry et al., Risk A djustment: The M issing Piece of M arket Competition, HEA LTH A FF., Spring 1996, at 171; Shoshanna Sofaer, Informing and Protecting Consumers Under M anaged Competition, HEA LTH A FF., Supp. 1993, at 76.

165. See Robert A. Berenson, Beyond Competition, HEALTH AFF., Mar.-A pr. 1997, at 171; J on Gabel, Ten Ways HMOs Have Changed During the 1990s, HEALTH A FF., May-J une 1997, at 134. Current trends are away from closed panels and gatekeeping. In 1988, $71 \%$ of insured workers were still in fee-for-service plans, with $18 \%$ in HMOs and $11 \%$ in PPOs. By 1991, fee-for-service had shrunk to $42 \%$, with $26 \%$ in HMOs, $22 \%$ in PPOs and $10 \%$ in point-of-service plans. Since then, however, PPO s have grown to $31 \%$ and point-of-service to $17 \%$, all at the expense of fee-for-service (which has dwindled to $18 \%$ ), while HM Os have increased more slowly to $33 \%$. See Peter T. Kilborn, Workers G etting G reater F reedom in H ealth Plans, N.Y. TIM ES, A ug. 17, 1997, at A 1.

166. See K aren D avis et al., Choice Matters: Enrollees' Views of Their H ealth Plans, HEA LTH A FF., Summer 1995, at 99. 
plans recruiting new subscriber groups, particularly those previously enrolled in indemnity insurance, advertise the size of their provider panels as a rough surrogate for quality. ${ }^{167}$ Furthermore, offering members the opportunity to remain with "their doctor" after joining a health plan reduces the number of transitional problems and improves performance in satisfaction surveys.

A nother reason for the breadth of managed care networks is that health plans have been able to control premium growth, and therefore to satisfy employers and other purchasers, even without highly selective contracting. ${ }^{168}$ This has been possible because of substantial preexisting capacity in acute care hospital beds and specialist physician services, allowing health plans to negotiate significant price concessions with a large number of providers. Even traditional closed-panel $\mathrm{H} \mathrm{M} \mathrm{O}$ s like $\mathrm{K}$ aiser F oundation $\mathrm{H}$ ealth Plan are farming out services to other facilities at favorable rates. ${ }^{169}$

Physician panic also has contributed to lack of network selectivity. Both specialists and primary care physicians have entered into contracts with managed care organizations almost indiscriminately, granting deep price discounts without any explicit assurance of patient volume. Consequently, most physicians are currently affiliated with many more health plans than would be predicted simply by population or referral base. ${ }^{170}$ In many cases, negotiated rates are so low that health plans have been able to eliminate primary care gatekeeping requirements, conferring on their products yet another choice-based marketing advantage. ${ }^{171}$

Finally, regulation has reinforced this trend by limiting the selectivity of provider networks. Subject to ERISA preemption, many states have enacted any-willing-provider statutes, which permit providers to affiliate as they choose, or freedom-of-choice laws, which allow consumers to consult without restrictions. ${ }^{172}$ Women in several parts of the country have won the right to visit ob-gyn physicians without a referral. ${ }^{173}$ Mandatory point-of-service

167. M ore detailed measures of quality that actually would be useful to consumers have been slow to develop. See A LICE G. GOSFIELD, GUIDE TO LEGAL ISSUES IN MANAGED CARE QUALITY 189213 (1996); Susan Edgman-L evitan \& Paul D. Cleary, What Information Do Consumers Want and N eed? HEA LTH A FF., Winter 1996, at 42.

168. W ith quality still an amorphous concept, most purchasers understandably focus on price, and premium growth has slowed, and even briefly reversed, during the last four years. R ecently, however, there are signs that premiums are rising again, probably signaling that the prior decrease reflected price-based bargaining rather than long-term changes in factors underlying medical inflation.

169. For example, cardiac surgery for Kaiser patients often is performed under contract by Stanford-U CSF M edical Center.

170. The continued importance of fee-for-service Medicare to most physicians' practices probably also has discouraged them from forming exclusive or near-exclusive affiliations with managed care plans.

171. See Rachel Kreier, HMOs Without Gatekeepers, A M. MED. NEWS, A ug. 5, 1996, at 1, 27. There are also variations on this theme, such as allowing patients to refer themselves to multidisciplinary specialty teams based on quality-related information about participating physicians. See L inda O. Prager, O xford's G ambit: Specialist Teams, D octor-Specific D ata, A M. M ED. NE WS, M ay 19,1997 , at $1,32$.

172. For a description of these laws and of other consumer protection initiatives in managed care, See PHY SICIAN PA YMENT REV. COMM'N, 1997 REPORT TO CONGRESS 235-45 (1997).

173. See CAL. HEALTH \& SAFETY CODE § 1367.69 (W est 1997). 
features for health plans have been enacted in one state and are being considered elsewhere. ${ }^{174}$ Legislatures and courts have adopted due process requirements for physician deselection. ${ }^{175}$ At the same time, the ease of price discounting has also eroded health plans' political resistance to these measures.

Enterprise liability, at least as envisioned by the Clinton A dministration in 1993, is not entirely compatible with today's managed care marketplace. ${ }^{176}$ A s a practical matter, health plans operating non-selectively have limited incentive and ability to control the delivery of care. Physician credentialing may be relevant in isolated circumstances where unlicensed individuals or persons who have been adjudged incompetent apply as participating providers, but it is seldom determinative of cost or quality in a world where panels are nonselective. In a health care system dominated by broad networks, most health plans have found it simpler to promote cost-effectiveness through general financial incentives and utilization review requirements than through specific provider reeducation and clinical direction. In any event, practice guidelines or other explicit clinical management tools would be inefficient deterrents to malpractice because physicians have contracts with so many different organizations.

This environment is also likely to retard private contracting to consolidate malpractice risk at the health plan level. A single health plan seldom accounts for a significant portion of any physician's patients, increasing the transaction costs to the health plan of providing malpractice insurance, indemnification, or a unified malpractice defense, and reducing the value of such arrangements to the physician. ${ }^{177}$ Perhaps reflecting this, the most common contractual arrangements are still ones in which health plans attempt to shed liability, not assume it, although professional associations and health care attorneys have successfully discouraged the use of very broad indemnification agreements favoring health plans. ${ }^{178}$

174. See S. 1150, 54th Leg. (Idaho 1997). Other states require that health plans offer point-ofservice options. See H.B. 46, 55th L eg. (M ont. 1997) (codified at 1997 M ONT. LA WS 165).

175. See N.Y. INS. LAW $\S 4803$ (MCK inney 1997) (establishing standards for managed care contracting); Potvin v. M etropolitan Life Ins. Co., 63 Cal. R ptr. 2 d 202 (Ct. A pp. 1997) (granting right to fair procedure for physician termination).

176. The use of managed care carve-outs also arguably has limited health plans' ability to centralize quality management. N ot only mental health services, but other areas, such as ophthalmologic and cancer care, may be subcontracted to specialized organizations whose treatment plans rarely are coordinated with one another. See R ichard G. Frank et al., R isk Contracts in M anaged M ental H ealth Care, HEALTH A FF., Winter 1995, at 50. On the other hand, as described below, carve-out providers may themselves develop effective quality management programs. See infra text accompanying notes 215-19.

177. As a consequence, only a physician's individual liability insurer has a risk management connection to all the physician's patients. However, there is much more underwriting capacity in the insurance markets today than 15 years ago when the first channeling programs were established between physicians and hospitals. See supra text accompanying notes 73-74. Therefore, it still may be cost-effective for managed care organizations to provide malpractice coverage for affiliated physicians under certain circumstances.

178. Even before the recent movement to legislate malpractice liability for managed care organizations, several states prohibited the use of broad indemnification or "hold harmless" provisions in managed care contracts, usually in response to physician complaints that contractually assumed 
Finally, the transition to managed care has created a disequilibrium in demand for as well as in supply of health care services. A Ithough sound data are scarce, annual turnover in managed care enrollment appears to be high, both in private insurance (as employers explore competitive alternatives) and in public programs such as M edicaid (because of strict eligibility criteria). U ntil the market stabilizes, it will be difficult to persuade managed care organizations to take a long-term view of quality or of relationships with patients, both of which are integral elements of enterprise liability.

\section{E. Individual A ccountability}

A considerable part of the debate over enterprise liability comes down to the question of the appropriate unit for accountability in modern health care. Traditionally, control-and therefore blame-rested with individual physicians. Today, however, there is increasing evidence that most errors in health care delivery, while human in proximate cause, are ultimately the result of faulty institutional processes. In this respect, health care is beginning to mirror other industries more than adherents to a purely professional model would like to admit. ${ }^{179}$

A the same time, the public is still loath to believe that anyone other than a doctor should be responsible for medical negligence. ${ }^{180}$ Part of this bias reflects the mystique that, for both scientific and self-serving reasons, has surrounded the modern medical profession. A nother part undoubtedly results from the history of conspiracies, cover-ups, greed, and inertia that, at least in the popular mind, characterizes the ethics of large, faceless corporations.

In the 1993-94 enterprise liability debate, preconceptions regarding accountability gave prominence to the question of whether malpractice liability should be shared between institution and individual, or completely transferred to the institution. No compelling logic prevents shared liability. A fter all, passengers on a bus that crashes are free to sue both the driver and the bus company. ${ }^{181}$ Nonetheless, the Clinton proposal recommended transferring liability. In part, transfer was intended as a symbolic benefit to physicians (though a completely unappreciated one, as it turned out). A dditionally, it was seen as a way to dislodge traditional insurance and litigation practices and the transaction costs, strategic behavior, and defensive risk management that they

liability was not covered by their malpractice insurance. See R.I. GEN. LA WS § 27-41-14(g) (1997) States currently attempting to impose malpractice liability on managed care organizations also are outlawing broad indemnification provisions in physician contracts, thereby foreclosing an obvious method of evasion. See S. 386, 75th L eg. § 88.002(e) (Tex. 1997).

179. See infra text accompanying notes $217-21$.

180. A ccording to a recent $\mathrm{H}$ arris poll, $95 \%$ of patients cited their personal physician as the individual who can have a positive effect on their safety during care. At the same time, patients appeared to discount the role of systems and institutions. See M edical M istakes: What Y our Patients Think, A M. MED. NEWS, 0 ct. 27, 1997, at 19.

181. Of course, unlike a typical doctor, a typical bus driver has neither a personal fortune nor millions in individual liability insurance. 
generate.

Nonetheless, transferred enterprise liability provides much clearer incentives for organizational improvement than does individual liability, particularly when many professionals and facilities typically are involved in the care of a single patient. ${ }^{182}$ In addition, industrial error reduction might be more successful without the scapegoating that invariably accompanies individual liability. However, market and regulatory trends apart from liability laws are reinforcing, rather than dispelling, public biases toward individual accountability.

Much as choice of physician dominates public debates over access to treatment in managed care, information about physicians controls discussions of quality. For example, reporting systems intended to provide clearinghouse information about doctors to state regulators and credentialing bodies for specific purposes are now under pressure to allow use by the general public. ${ }^{183}$ $M$ assachusetts recently became the first state to place physician disciplinary histories on-line, 184 and even the AMA has opened its practice files to the public electronically. ${ }^{185}$ This movement to make physician data widely available is largely oblivious to the academic debate between traditional "bad apple" models of quality improvement in medicine and new industrial theories of "shifting the curve." 186 Instead, it derives from technical advances such as

182. More generally, the public may be better protected from incompetent practitioners by the credentialing, disclosure, and quality management activities of managed care organizations than by direct government regulation of individual physicians. In an analogy to enterprise liability, this reasoning has stimulated interest in institutional licensure as a replacement for individual licensure. See Pew Health Professions Comm'n et al., Reforming health Care Workforce Regulation: Policy Considerations For The 21St Century 12 (1995); William M. Sage \& Linda H. Aiken, Regulating Interdisciplinary Practice, in REGULATION OF THE HEALTHCARE PROFESSIONS 71 (Timothy S. J ost ed., 1997).

183. M aryland, Florida, Delaware, Colorado, California, Vermont, and Connecticut have all considered measures to provide individual physicians' malpractice histories to the public. See Public A ccess to M alpractice D ata Proliferating in the States, MEDICINE \& HEA LTH, A pr. 7, 1997, at 1-2. The Medicare PR O program also has proposed making information about physicians publicly available. See Linda O. Prager, Physicians L eery A bout PRO Changes, A M. MED. NEWS, A ug. 18, 1997, at 3. Bills even have been introduced to make public the federal government's National Practitioner $D$ ata Bank, but as yet none have been enacted. See, e.g., Health Care Liability R eform and Quality A ssurance A ct of 1995, S. 454, 104th Cong., $\S 203$ (recommending study); Health Security A ct, H.R. 3600, 103d Cong., $\S 5005(d)$ (1993) (allowing public access); see also Health Care Quality Improvement A ct of 1986, Pub. L. N o. 99-660, 100 Stat. 3784 (codified as amended at 42 U.S.C. §§ 11101-11152 (1994)). However, questions have been raised about the quality of information in the federal databank and its overall effectiveness. See U.S. GENERAL A cCOUNTING OfFICE, HEALTH InFORMATION SYSTEMS: NATIONAL PRACTITIONER DATA BANK CONTINUES to Experience PR OBLEM S (1993); Lawrence Smarr, A Comparative A ssessment of the PIA A D ata Sharing Project and the National Practitioner Data Bank: Policy, Purpose, and Application, 60 LAW \& CONTEMP. PROBS. 59 (W inter 1997).

184. See 1996 M ass. A cts 307 (codified at MASS. GEN. LAWS ch. 112, 55 (1997)); Jeffrey P. D onohue, D eveloping Issues U nder the M assachusetts "P hysician Profile" A ct, 23 A M. J .L. \& M E D. 115 (1997); Paul Engstrom, D octor R ecords O nline: $H$ as M assachusetts $L$ et a $G$ enie O ut of the B ottle?, 2:11 MED. ON THE NET 1 (1996). California recently followed Massachusetts, see Linda O. Prager, California L atest A mong States R eleasing M ore D isciplinary D ata, A M. M ED. N EWS, M ar. 2, 1998, at 1.

185. A MA, D ata Services and Publications <http://www.ama-assn.org/physdata/physrel/physrel. htm> (visited O ct. 4, 1997).

186. "Bad apple" theories rely on eliminating incompetent physicians, while "curve shifting" 
the Internet and a consumerist generation that is now middle-aged, and as hungry for information about health care as it once was for data regarding cars and appliances. ${ }^{187}$

This is likely a progressive trend in most instances. Given the goals of enterprise liability, however, it may be problematic because improvement in institutional quality generally requires confidentiality and protection from retaliation to promote event reporting and analysis. B ecause they are new, for example, managed care organizations may have difficulty asserting privileges and immunities that originally were established for hospitals and other traditional peer review bodies. ${ }^{188}$ Moreover, the reputational threat to individual physicians of widespread publication of adverse events can alter behavior in unproductive ways. ${ }^{189}$ Consequently, the National Practitioner $D$ ata Bank and other malpractice reporting mechanisms may need to be restructured to reflect changes in litigation posture, settlement incentives, and quality-control activities produced by the imposition of liability on managed care organizations. Nonetheless, it will take time and luck to convince today's consumers to accept limits on information or constraints on malpractice litigation in the name of institutional quality improvement.

\section{F. L iability Insurance}

A s in many other areas of tort law, the widespread existence of liability insurance has exerted a marked influence on the compensatory and deterrent effectiveness of the malpractice system, as well as on the conduct of lawsuits. ${ }^{190}$ Consequently, the market for malpractice insurance frequently will determine the feasibility of contractual devices to reapportion liability in managed care, and will affect the direction and success of legal change. 191

emphasizes improving every physician's practice skills, including those at or above the standard of care. See Barry R. Furrow, The Changing Role of the $L$ aw in Promoting Q uality in $\mathrm{H}$ ealth Care: From Sanctioning Outlaws to M anaging Outcomes, 26 HoUS. L. REV. 147 (1989); J ohn E. Rolph et al., M alpractice Claims D ata as a Q uality Improvement Tool: II. Is Targeting Effective?, 266 J A M A 2093 (1991) (favoring systematic quality improvement). The two approaches are not mutually exclusiveshifting the curve makes it easier to detect outliers.

187. The author recently noticed a billboard advertisement in California for a physician information hotline, which asked the health care shopper: “D on't Y ou W ant to Examine $Y$ our D octor B efore He Examines Y ou?"

188. See L omano v. CIG NA Healthplan, Inc., 582 N.E.2d 1150 (O hio Ct. A pp. 1990) (finding that HMO does not meet definition of "medical review committee" for purposes of privilege). But see OHIO REV. CODE A NN. §§ 2305.25-2305.252 (West 1997) (reversing L omano).

189. For example, physicians often insisted upon clauses in managed care contracts allowing them to be terminated without cause because for-cause terminations must be reported to the National Practitioner Data Bank. To physicians' dismay, these clauses now are being used against them by managed care organizations.

190. See G ary T. Schwartz, The E thics and the E conomics of Tort L iability I nsurance, 75 C OR NELL L. REV. 313 (1990). For example, punitive damages are rare in medical malpractice litigation not only because of jury sympathy for physicians but because punitive damages often are uninsurable under law. See, e.g., CAL. CIV. CODE § 1668 (West 1997); CA L. INS. CODE $\S 533$ (W est 1997).

191. M arket exit or threat of exit by commercial malpractice insurers was a prime determinant of tort reform in the 1970s, and physician-owned mutual insurance companies have been key political and 
O ne argument in favor of enterprise liability is that corporate organizations are invariably experience-rated, while physicians are grouped only by class and location. ${ }^{192}$ The former arrangement provides a much clearer economic deterrent to malpractice. ${ }^{193} \mathrm{M}$ any health care institutions also have the financial wherewithal to self-insure up to high levels of risk, removing any dilutional effect of insurance on deterrence.

$\mathrm{H}$ owever, inflexibility in the liability insurance markets can be problematic for novel legal and contractual approaches to malpractice liability. ${ }^{194} \mathrm{M}$ anaged care is already pushing the envelope of traditional mal practice coverage. ${ }^{195} \mathrm{~F}$ or example, indemnification provisions in first-generation managed care agreements between physicians and health plans were often so one-sided that they constituted contractually assumed liability not covered by malpractice insurance. In addition, claims for personal injury in today's more corporate health care system sometimes can be brought against physicians in their capacities as directors, officers, or employers, and potentially can be excluded from coverage on those grounds. Finally, managed care requires even "treating physicians" to perform administrative care management tasks which may constitute a source of liability beyond the scope of their insurance.

Insurance laws and practices also limit the potential value to physicians of either mandatory or voluntary reapportionment of liability. As noted previously, physician malpractice premiums are not based on patient volume, so that any residual exposure beyond what is borne by a managed care organization-resulting perhaps from treating fee-for-service patients not enrolled in managed care-obviates much of the economic benefit of an enterprise liability arrangement. It is also unclear whether plaintiffs' attorneys would routinely dismiss individual physicians from suits if a solvent institutional defendant were available, although K aiser's mandatory arbitration system appears to function in that manner. A Iternatively, institutions might

policy actors since that time (including in the defeat of enterprise liability during the Clinton health care reform debate). It is possible that political efforts to restrict litigation and limit recovery through tort reform would be less successful if malpractice insurance premiums were simply part of the business expenses of large health care organizations. Historically, the visibility of large dollar costs nominally borne by individual practitioners, particularly well-regarded physicians in high-risk specialties, was central to the broad political appeal of malpractice-specific tort reform.

192. See Lori L. Darling, Note, The Applicability of Experience Rating to Medical Malpractice Insurance, 38 CA SE W. RES. L. REV. 255 (1987).

193. The effect of enterprise liability on deterrence apart from payment of damages is debatable. Individual physicians are probably more sensitive than corporations (especially small, transitory businesses) to reputational injury. On the other hand, favorable publicity can be critical to corporate success in a competitive market.

194. Physician malpractice carriers also are flexing their political muscle to protect their business against incursions by managed care organizations. See A.B. 3340, 1995-96 R eg. Sess. (Cal. 1996) (prohibiting managed care organizations from forcing or inducing physicians to accept malpractice coverage through them). The nominal justification for this bill was to ensure physician control over malpractice settlements, which was equated with physician independence from corporate care management decisions.

195. See E ugene R. A nderson \& J oshua G old, A re Y ou Covered?, A M. M E D. NEWS, D ec. 11, 1995, at 13. 
pay supplemental malpractice insurance premiums for affiliated physicians as a cushion against residual liability. H owever, such arrangements may be suspect under federal fraud and abuse laws or the Internal R evenue C ode. ${ }^{196}$

\section{VI}

\section{HOPEFUL SIGNSIN TODAY'SENVIRONMENT}

The preceding discussion demonstrates that, for various reasons, the recent expansion of managed care liability is taking place in a legal and business environment very different from that envisioned by the proponents of enterprise liability during the national health care reform debate. N onetheless, one can identify current trends in health law and management that in time may regenerate some of the legal and market characteristics that made enterprise liability attractive to policy-makers in 1993.

\section{A. A mendments to ERISA}

As discussed above, ERISA's uncertain preemptive effect both has sheltered managed care organizations from legal accountability and has led courts to reach results in individual cases that do not necessarily comport with larger issues in health care financing and delivery. ${ }^{197}$ A necessary step to improve consistency in malpractice litigation involving health care institutions therefore is to remedy the imbalances resulting from E RISA.

As previously mentioned, the ERISA statute includes few substantive provisions governing welfare benefit plans, but does impose fiduciary duties and reporting requirements on plan sponsors and certain contractors. ${ }^{198}$ Because of these obligations, an important potential source of liability for both employers and the managed care organizations with which they do business is inadequate disclosure of information to beneficiaries. For example, two recent cases have held that employee benefit plans and their agents may violate their fiduciary obligations under $\S 504(a)(1)$ of ERISA if they fail to reveal the financial incentives for cost containment to which their affiliated physicians are subject. 199 Claims are also being brought under ERISA relating to employers'

196. M oreover, risks of offending these laws vary according to organizational structure, creating uneven incentives. Providing malpractice coverage is more difficult for nonprofit than for for-profit entities because of charitable purpose restrictions. It also is more difficult for hospitals than for insurance organizations because of M edicare kickback concerns. The IR S recently decided to allow nonprofit hospitals to provide below-market liability insurance to physicians, but only for a limited time after recruitment. See J ulie J ohnsson, IR S F eeling Charitable on D octor R ecruitment I ncentives?, A M. MED. NEWS, J une 23/30, 1997, at 1.

197. See supra notes 108-15.

198. Under recent judicial interpretations of ERISA, beneficiaries may bring breach of fiduciary duty claims on their own behalf. See V arity Corp. v. H owe, $116 \mathrm{~S}$. Ct. 1065 (1996). Previously, such actions were permissible only if brought on behalf of the plan, like shareholder derivative suits.

199. See, e.g., Shea v. Esensten, 107 F.3d 625 (8th Cir. 1997) (finding that failure by HMO to disclose financial incentives states a claim for breaching fiduciary obligations under ERISA ); D rolet v. Healthsource, Inc., 968 F. Supp. 757 (D.N.H. 1997) (denying motion to dismiss and finding HM $O$ qualified as fiduciary under ERISA for disclosure purposes). But see Weiss v. CIGNA H ealthcare, Inc., 972 F. Supp. 748 (S.D.N.Y. 1997) (stating that defendant was not required to disclose financial 
decisionmaking standards as plan sponsors. In one recent coverage case, a plan's summary affirmance of the decision of its administrator insurance company was overturned by the court because the employer's ruling was based on insufficient information. 200 In these ways, ERISA can be used to induce employers to supervise more carefully the actions of the managed care organizations with which they do business. ${ }^{201}$

In addition, the Department of Labor ("DOL"), which promulgates regulations under ERISA, is finally considering setting substantive standards for employee health plans, possibly including more explicit quality assurance requirements. DOL also has filed amicus briefs supporting the proposition that medical malpractice is not a benefits determination and therefore that malpractice claims are not preempted by ER ISA .202

Finally, Congress is considering several bills that would fill the ERISA vacuum directly. ${ }^{203}$ For example, Representative Stark has introduced legislation to hold ERISA plans liable for medical malpractice if injuries result from cost-containment practices. ${ }^{204}$ Taking a different approach, Representative Norwood has authored comprehensive managed care legislation that includes a provision amending ERISA's preemption clause to exclude preemption of personal injury and wrongful death claims against insurers or third-party administrators.205 A direct federal remedy is more likely to produce a consistent view of managed care liability than if it is subject to different tort law in each of the fifty states, but either approach would free

incentives because disclosure obligation belongs to plan administrator, not every fiduciary). Of course, even cases allowing claims for inadequate disclosure under ERISA do not provide a meaningful damage remedy. See supra text accompanying notes 105-06.

200. See Crocco v. X erox Corp., 956 F. Supp. 129 (D. Conn. 1997) (finding that employer who allowed benefits decisions to be made by utilization management company violated ERISA by not performing a full and fair review of plaintiff's mental health claim); see also B ooton v. Lockheed M ed. Benefit Plan, 110 F.3d 1461, 1464 (9th Cir. 1997) (stating that "to deny the claim without explanation and without obtaining relevant information is an abuse of discretion").

201. The employer was held responsible in Crocco because the plan document reserved ultimate discretion to it. See Crocco, 956 F. Supp. at 137.

202. See DOL O pposes Malpractice Preemption; L egislative Response Appears Unclear, BNA'S HEALTH L. REP., A pr. 3, 1997, at 503.

203. The Health Insurance Portability and A ccountability A ct of 1996 (HIPA A ), Pub. L. N o. 104191, 110 Stat. 1936, also known as the K assebaum-K ennedy A ct, signaled a new willingness on the part of Congress to regulate ERISA plans directly in federal health care legislation. Prior to 1995, most efforts to amend ERISA were mired in the broader politics of labor-management relations.

204. See M anaged C are Plan A ccountability A ct of 1997, H .R . 1749, 105th Cong.

205. See Patient A ccess to Responsible Care A ct of 1997 (PARCA), H.R. 1415, 105th Cong. In response to employers' concerns, and so as not to jeopardize the rest of PARCA should liability reform fail, R ep. N orwood also has introduced a stand-alone bill, the R esponsibility in M anaged Care A ct of 1997, H.R. 2960, 105th Cong. (introduced N ov. 8, 1997). H.R. 2960 eliminates preemption of claims against persons that provide "insurance or administrative services" to an ERISA plan, but purports to shield employers by prohibiting indemnification requirements by plans and limiting employer liability to situations where employers' exercise of discretionary authority causes injury. The Employee Health Insurance A ccountability Act of 1997, S. 1136, 105th Cong., submitted by Representative Durbin, similarly removes malpractice, personal injury, and wrongful death claims from the scope of preemption. 
courts from the strained reasoning necessary under current law. However, business interests have awakened to the litigation and cost implications of major changes to ERISA preemption, portending a vigorous debate in Congress. $^{206}$

\section{B. New D elivery Systems}

As discussed previously, the market has moved away from tightly integrated, health plans with selective provider panels. ${ }^{207}$ However, the fact that health plans currently lack the contours of efficient, liability-bearing entities as anticipated by enterprise liability theory does not necessarily imply that managed care organizations will never be suited to that role.

A bove all, the market is certain to evolve further. In particular, many of the factors alluded to as fostering broad, overlapping networks are likely to change. Competition has already reduced excess capacity significantly in some parts of the country, and eventually it will diminish elsewhere. This will make it difficult for health plans to maintain low premiums without engaging in more specific management practices, many of which will depend on network selectivity. A the same time, physicians will feel less pressure to become affiliated with every health plan, preferring instead to negotiate narrowly in exchange for assurances of patient volume or other benefits.

M oreover, new organizations may step into the role previously envisioned for health plans. In California and a few other regions, large medical groups are subcontracting with health plans to accept insurance risk for enrolled populations based on a global capitation amount or a percentage of premium dollars. ${ }^{208}$ These groups have many of the attributes that made health plans theoretically attractive repositories of malpractice liability under managed competition, as well as other advantages stemming from their physicianoriented structure and history.

M ore so than insurance organizations, capitated medical groups profit from strict medical management, and aspire to a collegial rather than adversarial relationship with their member physicians. ${ }^{209}$ By definition, physicians are tied

206. See Geri A ston, L iability Provision Could Derail Managed Care Reform, A M. MED. NEWS, Feb. 9, 1998, at 1, 29. A major sticking point is whether managed care organizations can be held accountable without directly subjecting employers to liability.

207. See supra text accompanying notes 163-65.

208. See James $C$. Robinson \& Lawrence P. Casalino, Vertical Integration and O rganizational Networks in Health Care, HEA LTH A FF., Spring 1996, at 7.

209. Unlike capitated medical groups, physician practice management companies ("PPM s") are uncertain repositories for malpractice liability. Whereas hospitals that acquire the practices of affiliated physicians, and even some physician-hospital organizations ("PHO s"), often hope to achieve a degree of clinical integration, PPMs tend to be large, entrepreneurial organizations primarily designed to offer sophisticated financial expertise to widely dispersed medical groups. A Ithough PPM 5 are starting to assume responsibility for utilization management and quality assurance, existing organizations have profited primarily by securitizing physicians' otherwise illiquid practice assets. See James C. Robinson, Consolidation of Medical Groups into Physician Practice Management Organizations, 279 J A M A 144 (1998); A lbert E. Barnett, Protecting D octor-Patient Relationship in PPM sIsn't E asy, A M. M ED. NEWS, Feb. 9, 1998, at 17. 
exclusively to the group, so that populations of patients can be aggregated under the group's sole responsibility. A Iso, medical groups generally employ their physicians, and can do so without violating laws prohibiting the corporate practice of medicine. Thus, in most cases, medical groups already bear respondeat superior liability for their physicians' activities. ${ }^{210}$ Furthermore, medical groups typically purchase liability insurance as a unit, and many are large enough to substitute self-insurance or off-shore captive subsidiary arrangements for commercial coverage. ${ }^{211}$ Finally, although they lack direct contractual opportunities at the point of health plan enrollment that could be used to structure alternative dispute resolution systems, medical groups frequently offer standardized arbitration agreements to patients at the point of service.

A nother potential home for unified malpractice liability is the disease management program. ${ }^{212}$ A s managed care moves from price-based bargaining with surplus providers to clinical cost-containment, and as risk-avoidance strategies are regulated or competed away, the basic fact that a few chronic diseases account for the bulk of medical expenditures will take on tremendous importance. ${ }^{213}$ Organizations that can provide these patients with high-quality, cost-effective care through an at-risk subcontract from health plans will be essential to the continued success of managed care. While displaying more of a physician focus than have most insurers, disease management programs usually will include a greater diversity of non-physician health professionals and a larger array of affiliations with facilities, pharmaceutical suppliers, and ancillary service organizations than will capitated medical groups. ${ }^{214}$ Furthermore, because the patients they treat are at particularly high risk for medical mishaps, disease management programs may be effective bearers of malpractice liability despite their limited impact on the treatment of a health plan's enrolled population considered as a whole.

Capitated medical groups and disease management programs will have added importance in the evolving managed health care system because of the potential for direct contracting between these entities and employers. For example, both types of organization are large enough to allow employers to

210. The percentage of physicians practicing as employees rose from $24.2 \%$ in 1983 to $45.4 \%$ in 1995. See E mployed Physicians, A M. M ED. NEWS, D ec. 23/30, 1996, at 2.

211. Unlike insurer- or hospital-sponsored integrated delivery systems, group practices also enjoy exemptions from federal fraud and abuse laws that make it less problematic to provide malpractice coverage in a centralized fashion.

212. See R egina E. Herzlinger, MARKET-DRIVEN HEALTH CARE: Who WINS, Who LOSES IN THE TRANSFORMATION OF AMERICA'S LARgESt SERVICE INDUSTRY (1997) (discussing "focused factories" for disease management).

213. See Gray E IIrodt et al., E vidence-B ased D isease M anagement, 278 J A M A 1687 (1997) (stating that $10 \%$ of employees with severe or chronic diseases may consume $70 \%$ of a company's health care costs).

214. See G reg B orzo, Drug Firms Expand into Patient Care, A M. MED. NEWS, J une 24, 1996, at 1, 7-8. The corporate connection between disease management programs and drug or device manufacturers also suggests that medical malpractice and product liability claims may become more closely linked. 
delegate fiduciary obligations to them lawfully and practically under E R ISA.

\section{Targeted R egulation}

$M$ anaged care regulation also may lead to improved quality management at the health plan level. State insurance and HMO licensing authorities have imposed a variety of process-based standards on health plans. L arge employers and group insurance purchasers are doing the same, as are private accrediting organizations such as the National Committee for Quality A ssurance ("NCQA") and the Joint Commission on the A ccreditation of Healthcare O rganizations ("JCA HO"). 215 So too are M edicare and M edicaid. U Itimately, it is likely that Medicare will assume a dominant role in the regulation of managed care. The $\mathrm{H}$ ealth Care Financing $\mathrm{A}$ dministration may achieve this end directly, or may do so by relying on organizations such as NCQA and JCA HO.

For example, selection and credentialing requirements for health plans now approach the level of detail traditionally reserved for hospital medical staffs. This eventually may compel careful oversight of individual physician quality. $M$ andatory reporting and disclosure laws based on databases such as HEDIS or other standardized comparative quality measures may also force health plans to manage their provider networks more closely. ${ }^{216}$ A dditionally, regulators are monitoring utilization review, consumer grievance, and dispute resolution practices for an increasingly broad range of managed care entities, potentially improving recognition of injury and access to compensation.

\section{Industrial Strategies for E rror R eduction}

$M$ any aspects of modern industrial society, especially those operating under time pressure with heavy through-put, have the potential to inflict serious personal or economic injury. 217 Within these "high-reliability industries" which range from nuclear power and air transport to banking and mail carriage- a new science of human factors engineering has arisen. 218 By examining workplace conditions and studying human responses to them, major

215. See J ohn K. I glehart, The National Committee on Q uality A ssurance, 335 NEW ENG. J. MED. 995 (1996).

216. HEDIS stands for "Health Plan and Employer Data and Information Set." See 1997 Comparative Performance Data Sourcebook (John Reichard et al. eds., 1996); William M. Sage $\&$ D avid A nderson, Health Care D isclosure Requirements, in HEALTH LA W HA NDBOOK 185-205 (A lice G. G osfield ed., 1997).

217. For example, litigation over fatigue in work settings is increasing. See Martin Moore-E de, When Things G o B ump in the Night, 81 A .B.A . J ., J an. 1995, at 56.

218. From an industrial perspective, medical quality expectations seem quite low, and medical malpractice law extremely forgiving. For example, a 99.9\% "error-free" level would mean that 84 unsafe airplane landings occurred each day in the $U$ nited States, that 16,000 letters were lost each hour by mail carriers, and that banks made 32,000 check processing errors each hour. By contrast, the apparent frequency of inpatient medication errors ranges from $0.2 \%$ of drug administrations, if selfreporting is used for assessment, to $10 \%$ if chart review is combined with computerized detection methods. See Lucian Leape, A ddress at the Examining Errors in Health Care Conference ( $\mathrm{Oct} .13$, 1996). 
advances have been made in corporate performance and in consumer, worker, and public safety.

These processes are being slowly adapted to medicine. The institutional rejuvenation needed to meet competitive conditions in managed care has been accompanied by a new industrial jargon of quality- terms such as "total quality management" and "process reengineering." A s one scholar has observed: "The industrial vision of medicine has brought with it, along with its many adverse effects ... the conceptualization of health care as a collection of processes interacting within a larger system." 219

Spurred by high-profile tragedies at world famous cancer treatment centers such as $\mathrm{M}$ emorial-Sloan K ettering in $\mathrm{N}$ ew $\mathrm{Y}$ ork and $\mathrm{D}$ ana F arber in B oston,220 even mainstream medicine is redirecting its approach to error reduction from individual punishment to institutional prevention. For example, the A merican $M$ edical A ssociation and other sponsors recently established a $\mathrm{N}$ ational Patient Safety Foundation to fund a multi-year initiative to study process-based safety in health care. 221

\section{E. Coordinated R isk M anagement}

A final possibility is that malpractice insurers pursuing new business will generate coordinated quality improvement activities even without formal arrangements transferring malpractice liability from individuals to institutions. The lines between physician liability insurers and insurers for institutions such as hospitals are blurring as new delivery structures in managed care create competitive opportunities. ${ }^{222}$ In addition, risk management is now performed using sophisticated data systems that collect information regionally or nationally. Managed care organizations can purchase access to these risk management databases to assist in tasks such as selecting providers and developing practice guidelines.

H owever, there may be limits to innovation in the insurance market. The current abundance of insurance capacity for health care-whether malpractice liability coverage or stop-loss protection for entities bearing health insurance risk - derives entirely from economic forces external to the health care system. These include the absence of major insured natural catastrophes since Hurricane A ndrew in 1992, extremely high investment income from stocks, bonds, and real estate, and the decision to allow corporate participation in Lloyds of London. Such favorable circumstances cannot last indefinitely.

219. J erry A vorn, Putting A dverse D rug E vents into Perspective, 277 J A M A 341 (1997).

220. See generally Christine Gorman, The D isturbing Case of the Cure That K illed the Patient, TIME, A pr. 3, 1995, at 60 (describing the death of B oston G lobe health columnist B etsy Lehman from a gross overdose of cancer chemotherapy).

221. See Lisa B elkin, H ow Can We Save the N ext Victim?, N.Y .T. M A G., J une 15, 1997, at 28; J anice Perrone, Designing a Safer, Smarter H ealth Care System, A M. M E D. NEWS, O ct. 27, 1997, at 1, 33; L inda O. Prager, Reducing M edical E rrors, A M. MED. NEWS, N ov. 4, 1996, at 1, 29.

222. The London reinsurance market is playing an important role in this process. See Paul $R$. M cG inn, U.S. Physician Coverage a B oon for L ondon Reinsurers, A M. MED. NEWS, A ug. 18, 1997, at 24. 
Future downturns in underwriting and investment cycles may restrict the availability of innovative forms of pooled or segregated coverage for managed care organizations much as it did in earlier decades with respect to insurance for individual physicians. 223 In fact-whether the result of external forces, the potential for expanded liability in managed care, or excessive discounting accompanying the loss of protected physician markets-malpractice insurers are al ready threatening substantial premium increases. ${ }^{224}$

VII

\section{RESTORING A COHESIVE FRAMEWORK FOR ENTERPRISE LIABILITY}

The fundamental objections to enterprise liability as an impetus to quality improvement in 1993 were twofold: that organizational intrusion in clinical decisions was always counterproductive, and that malpractice litigation was unrelated, or at least tangential, to achieving public policy goals. The former concern has been rendered moot by the managed care juggernaut. However, the latter issue still remains a valid subject for debate.

The potential for enterprise liability to improve managed care ultimately depends on the underlying utility of malpractice law as a social tool.225 Systematic enterprise liability as proposed during the health care reform debate arguably could have improved access to compensation, facilitated quality improvement, and reduced transaction costs. If current trends in managed care continue, however, enterprise liability will evolve only piecemeal through reactive judicial decisions and state legislation.

With respect to compensation, there is little reason to expect improvement without comprehensive reform, except in the narrow sense that the weakening of ERISA preemption may provide remedies that did not previously exist. A S is true for tort litigation generally, however, only a few plaintiffs are likely to benefit. By contrast, systematic enterprise liability proposals rely on a combination of regulatory oversight, alternative dispute resolution, and limits on litigation exposure to ensure that more grievances relating to injury are aired while controlling the costs of resolving them. A bsent such measures, managed care entities will be reluctant to acknowledge their clinical responsibilities without a fight.

$\mathrm{N}$ either is the deterrent effect of medical malpractice law certain to be furthered by current trends in managed care liability, especially without some mechanism to bring a larger percentage of adverse events to dispute resolution. The vagaries of ERISA, the non-selective character of current managed care networks, and the continued fixation on individual physician accountability all tend to perpetuate the small numbers problem of litigation correlating poorly

223. On the other hand, the eventual public securitization of insurance may increase underwriting capacity to an even greater degree.

224. See L inda O. Prager, M arket U pheaval Threatens L iability Rate H ikes, A M. MED. NEwS, Feb. 16,1997 , at 1,33 .

225. SeeThe URBA I NSTITUte, supra note 13 , at 28. 
with demonstrable quality. Furthermore, patchwork imposition of potentially crippling liability may deter innovation in health care delivery and inadvertently channel managed care into less efficient, lower quality forms of organization.

In addition, the tort reform climate in many states limits the usefulness of private arrangements to redistribute liability in managed care systems. ${ }^{226}$ Without caps on non-economic damages or clearly permissible forms of structured dispute resolution, any health plan that individually offers enterprise liability to its network physicians may find itself at a competitive disadvantage compared to other plans in its area that do not assume liability. A the same time, the uncertain integrity of the ERISA shield may discourage contractual reapportionment of liability between seemingly protected and seemingly unprotected parties.

There are also reasons to be concerned about the cost of managed care liability as it is developing. B oth legislation creating new causes of action and the fragmentation of managed care networks discourage a major theoretical advantage of systematic enterprise liability: the ability to establish a contractual alternative to traditional litigation. Moreover, despite its beneficial effect on compensation for injured plaintiffs, the filling of the ERISA vacuum-either by judicial decisions weakening preemption or by changes to ERISA itselfcarries with it potentially high transaction costs. ${ }^{227}$ In addition, unlike systematic enterprise liability, which consolidates claims in a two-party action, legislation or case law allowing suits to be brought against additional parties increases strategic behavior by plaintiffs and finger-pointing among defendants. 228

The best solution to these problems is to enact federal legislation that creates a uniform, national approach to personal injury litigation arising from medical care. Federal intervention is both inevitable and desirable. It is inevitable because, no matter how courts finesse ERISA preemption to accommodate equities of particular cases, there is no principled way to

226. N ot only have some state legislatures opposed tort reform, but several state constitutions have been interpreted as prohibiting limits on damages. See, e.g., B est v. Taylor M ach. W orks, N os. 8189081893, 1997 III. LEXIS 478 (III. Dec. 18, 1997) (striking down Illinois' Civil Justice Reform A mendments of 1995 , including a $\$ 500,000$ cap on non-economic damages).

227. The cost implications of expanded liability are speculative, as indeed are the costs of the current malpractice system. In 1991, malpractice insurance premiums and self-funded reserves totaled $\$ 9$ billion, in itself a large sum but only about $1 \%$ of total health care spending. See THE URBAN INSTITUTE, supra note 227, at 8. "Defensive medicine" is arguably much greater, but includes necessary interventions as well as wasteful ones. See K essler \& M cClellan, supra note 9 . In any event, it seems safe to assume that greater liability means higher administrative cost, which will be passed on to health plan sponsors and beneficiaries in the same way that fee-for-service malpractice costs are ultimately borne by patients.

228. One exception to this is the Dukes trend of allowing claims only for vicarious liability. Since the managed care organization's liability is derivative of the liability of the physician or the hospital, there is less incentive for each to point the finger at the other, especially because managed care organizations held vicariously liable could bring contribution claims against insured physicians. With direct claims like Corcoran, on the other hand, there frequently will be incentives for physicians to testify against managed care organizations in exchange for being dropped (or never named) as defendants. The lack of cohesiveness of managed care networks encourages these maneuvers. 
distinguish benefit determinations from treatment decisions in managed care. Consequently, injured patients cannot obtain fair and equitable compensation absent federal legislation.

A federal approach is desirable because we will have a rational, accessible system offering cost-effective, population-based health management only if we encourage clinical and managerial innovation to create it. This implies ensuring equal risk and opportunity for managed care enterprises rather than enforcing liability rules that arbitrarily favor certain organizational forms over others. It also means adopting inclusive strategies for dispute resolution that serve patient populations broadly rather than offering windfalls to privileged winners in a litigation lottery. N either of these goals will be achieved as long as legal rights and remedies depend on outdated or artificial distinctions that fail to acknowledge the increasing diversity of health care organizations and the very high expectations society puts upon them.

Federalizing managed care liability makes sense whether or not the $U$ nited States ever reaches national consensus regarding a health care entitlement. In the absence of comprehensive health reform, the current link between private employment and health insurance will almost certainly stand as a second-best solution. ${ }^{229}$ In that event, maintaining uniform liability rules under ERISA for multistate businesses and the managed care organizations that serve them is likely to improve access and reduce costs at the margin. A the same time, the Health Care Financing Administration is rapidly becoming the principal regulator of managed care as the percentage of Medicare beneficiaries in prepaid health plans rises. ${ }^{230}$ Furthermore, the federal government is already policing managed care quality through a variety of enforcement mechanisms tied to personal injury. ${ }^{231}$

If federal legislation involving managed care liability is proposed, it should be measured against the following principles:

(1) A n ideal law would grant all plaintiffs equal rights and remedies,

229. The future of employer-based health care is a subject of considerable debate. O ne important issue with implications for liability is whether employers continue to sponsor defined-benefit plans that assure workers of medically necessary care, or whether they elect to shift the risks of adverse selection and medical inflation to other parties by limiting their financial responsibility to a defined dollar contribution (perhaps using a medical savings account). Only in the former situation would employers maintain close enough ties to health care delivery to warrant imposition of liability.

230. This is an example of history repeating itself. M edicare fee-for-service reimbursement policies largely determine the structure and conduct of the health care industry, despite the supposed primacy of state laws governing professional licensure and insurance. M oreover, the Balanced Budget A ct of 1997 ("BBA ") radically altered M edicare managed care, enacting a M edicare+Choice program that presupposes an increasing diversity of organizational structures to finance and deliver managed care services. See Pub. L. 105-33, 111 Stat. 251 (1997). Medicare and Medicaid also have become the primary vehicles for expanding health coverage to children under the BBA and to early retirees if more recent legislative proposals are enacted.

231. In addition to private suits under E MTA LA , federal prosecutors are beginning to bring actions against plans and providers under the False Claims A ct and other antifraud statutes for failing to provide adequate care to M edicare and Medicaid beneficiaries. See Kristen Hallam, Bragging Rights: Report Shows Fraud Probes A re Paying Big D ividends, M OD. HEA LTH CA RE, Feb. 2, 1998, at 8. 
regardless of the public or employer sponsorship of the defendant managed care organization.

(2) A n ideal law would include regulatory oversight to promote broad patient access to cooperative dispute resolution and timely compensation.

(3) A n ideal law would constrain damages to amounts necessary to provide adequate compensation and quality improvement incentives, without deterring innovation.

(4) An ideal law would permit reasonable, private contractual modifications to liability and dispute resolution by patients, providers, health insurers and/or plan sponsors.

(5) A n ideal law would encourage voluntary error reporting and internal institutional quality improvement.

(6) A n ideal law would not favor certain organizational structures or forms of care management over others.

What specific changes might be warranted? A bove all, the uneven effects of ERISA preemption are both logically and ethically indefensible. Moreover, line-drawing in a rapidly changing industry is practically impossible. Congress therefore should create uniform rights and remedies for personal injury claims (both malpractice allegations and coverage denials) arising from medical care. These would apply equally to insured ERISA plans, self-funded ERISA plan administrators, commercial insurers and $\mathrm{HMOS}$, and any entity certified to participate in Medicare+Choice, ${ }^{232}$ as well as to individual health professionals, provider organizations, and subcontractors for ancillary services. ${ }^{233}$

To avoid placing the entire managed care industry on trial every time a mishap occurs, liability should be premised on actual causation of injury or vicarious responsibility therefor, paralleling traditional medical malpractice causes of action. Tangential claims- such as allegations of breach of fiduciary duty, bad faith breach of contract, or infliction of emotional distress-should be preempted or, if brought under ERISA or other federal statutes, strictly

232. The eligibility of Provider-Sponsored Organizations ("PSO s") to participate in Medicare+Choice confirms the absurdity of ERISA's current distinction between benefit determinations and treatment decisions. The reason for allowing PSO s was to encourage physicians to form and manage health plans.

233. A n important detail to address is the division of responsibility between state and federal courts. A difference between adding substantive force to ERISA and removing personal injury claims from preemption is that the former could greatly increase the workload of federal courts while the latter (diversity jurisdiction aside) might decrease it. 
limited. ${ }^{234}$ In addition, liability based on financial incentives in managed care contracts should be constrained, on the theory that regulatory bodies will adequately address such provisions through substantive prohibitions and disclosure obligations. ${ }^{235}$

Similarly, damage awards should be geared to achieving clear public policy objectives, not venting popular disaffection with managed care. Because compensatory damages are the norm in medical malpractice litigation against individual physician defendants, and generally provide adequate recovery for injured patients (and their attorneys), punitive damages should be prohibited except in cases of willful harm. ${ }^{236}$ This would make liability exposure more predictable for managed care organizations and therefore easier to insure or self-insure.

Other refinements also could improve access to compensation, facilitate quality improvement, and reduce administrative costs. For example, Congress should build on current Medicare regulations to create a uniform processapplicable both to benefits determinations and to instances of alleged malpractice-for airing grievances, appealing care management decisions, and resolving disputes over alleged injury. This process might be exclusive, or might co-exist with state laws governing alternative dispute resolution. ${ }^{237}$ Federal law also should protect legitimate organizational quality improvement activities from private litigants by guaranteeing substantive immunity under certain circumstances and by enacting liberal procedural rules that ensure confidentiality and non-discoverability. ${ }^{238}$ Finally, all potential defendants should be required to carry adequate malpractice insurance or comply with solvency safeguards, while existing laws such as anti-kickback regulations and tax code provisions that discourage health care organizations from providing liability coverage to affiliated physicians should be amended.

\section{VIII}

\section{CONCLUSION}

Since the failure of national health care reform, the terms of the debate over enterprise liability have changed. In 1993, the challenge was to

234. A mong other things, this generally would shield employers and other plan sponsors from liability unless they were involved very closely in clinical decisions.

235. This would have the beneficial effect of rewarding health plans that delegate care decisions to providers and provider groups. It also would reverse current law, which tends to encourage rule-based benefit decisions that are protected most clearly by ERISA preemption. O ne should note that judges already have considerable discretion to circumscribe legal claims through evidentiary rulings. Evidence regarding financial incentives, while sometimes relevant, tends to be so prejudicial that courts might be justified in deeming it inadmissible.

236. Furthermore, attorneys' fees presently are available to prevailing plaintiffs under ERISA, and should continue to be.

237. If state participation is desired, Congress should reverse Casarotto's interpretation of the Federal A rbitration A ct. See supra text accompanying notes 160-61.

238. Cf. H ealth Care Improvement A ct of 1986, 42 U .S.C. § 11101 (1994) (providing for immunity from antitrust liability for peer review activity). 
reinvigorate a stagnant malpractice system that barely was aware of the nascent managed care industry. Now the challenge is to make sense of, and bring discipline to, liability laws that are straining to assert control over a rapidly expanding competitive marketplace. This article has argued that federal legislation is needed to level the playing field among different types of health plans and providers, and to create a malpractice system that performs better in managed care than it has in fee-for-service medicine.

A s in 1993, of course, this will be an uphill political fight. A promising sign is that each constituency has something to gain from compromise, both in maintaining its own coalition and in reaching agreement with opposing parties. For example, consumers and trial lawyers can loosen ERISA preemption, but must accommodate physicians' concerns about unbridled liability. Similarly, insurers can protect themselves from jury outrage, but must accept a stronger regulatory framework for treatment decisions and redress of injury.

Furthermore, it remains possible that systematic forms of enterprise liability that incorporate measures to improve the compensatory and deterrent effects, as well as the administrative efficiency, of tort law will be tested. The Physician Payment Review Commission and the A merican College of Physicians have endorsed federal support for demonstration projects and for the evaluation of existing examples of enterprise liability. ${ }^{239} \mathrm{M}$ ore recently, the Robert Wood Johnson Foundation funded a demonstration of enterprise liability in combination with other malpractice reforms in U tah. 240

To summarize, the current movement toward managed care liability is an important trend with implications for both the cost and quality of A merican health care. Most significantly, it signals a new recognition of the ethical and legal responsibilities of health care institutions in the modern era. E ventually, this sentiment may erode the preconceptions about accountability in health care that continue to impair the integration of medical malpractice law with the industrial foundation and regulatory framework of our managed health care system. Without a careful, coordinated approach, however, the attribution of liability to managed care organizations will not realize its full potential to improve the performance of the tort system or the health care system in cases of medical error.

239. See PhysiCian Payment Rev. Comm'n, 1995 Report to Congress 317-18, 327-28 (1995); 1994 PPR C REPORT, supra note 63, at 289-90, 299-300; A merican College of Physicians, Beyond MICRA: New I deas for L iability Reform, 122 A NNA LS I NTER NA L MED. 466, 470-71 (1995). The final version of the Clinton A dministration's proposed $\mathrm{H}$ ealth Security A ct similarly called for state-based demonstration projects of enterprise liability. See H ealth Security A ct, H.R. 3600, 103rd Cong. § 5311 (1994).

240. See S. K eith Petersen, N o-Fault and Enterprise L iability: The View From Utah, 122 A NNALS INTER NA L MED. 462 (1995); U tah Seeks Test of Enterprise Liability, MED. LIABILITY M ONITOR, Dec. 13,1994 , at 1. 